\title{
Risks, benefits size and clinical implications of combined oral contraceptive use in women with polycystic ovary syndrome
}

Sebastião Freitas de Medeiros ${ }^{1,2}$

\begin{abstract}
Background: Polycystic ovary syndrome (PCOS) is a complex condition with high risk for dyslipidemia, dysglycemia, venous thromboembolism, cardiovascular disease and metabolic syndrome. Because the combined oral contraceptive (COC) use has also been associated with impaired fasting glucose, insulin resistance and increased risk of thromboembolism disease, it is rationale to think that the combination of oral contraceptive and PCOS could make it worse or increase the risks.
\end{abstract}

Objective: To examine the current data regarding potential additional risks and benefits of contraceptive use, highlights the major gap in knowledge for designing future studies and, when possible, suggests an adequate COC formulation for a determined PCOS phenotype.

Methods: English-language publications reporting on the influence of COCS in the development of venous thromboembolism in PCOS patients published until 2017 were searched using PubMed, Cochrane database, and hand search of references found in consulted articles. Ranges of collected data are given; the pooled data are presented as median and first and third quartiles. Wilcoxon signed-ranks test for paired samples was used to compare before-after original data. $P$ value was set at 0.05 .

Results: Most of COCs preparations significantly decrease androgens, and increase sex-hormone binding globulin. Therefore, the benefits of COCs are clear in patients with proved hyperandrogenemia. Regarding the impact of COCs on carbohydrate metabolism of PCOS subjects, the data were inconsistent but they tended to show no additional risk. Regarding lipids, most COCs consistently increased high-density lipoprotein cholesterol, triglycerides and total cholesterol concentrations but the clinical implications of these changes need additional studies.

Conclusion: The review showed consistent beneficial effect of COCs, particularly for hyperandrogenemic PCOS patients. The benefit size of COC's use by normoandrogenemic PCOS patients is uncertain and need more investigation. The effects of COC use on carbohydrate metabolism of women with PCOS are still unresolved since most studies are observational but the current results demonstrated that COCs do not make their levels worse and may improve insulin sensitivity. The impact of COCs on lipids of PCOS patients seems to be clearer and most preparations increase total cholesterol, high-density lipoprotein cholesterol and triglycerides. In summary, it is important to balance the potential benefits and risks of the COCs individually before prescribing them for PCOS women.

Keywords: Polycystic ovary syndrome, Contraception, Oral contraceptive, Progestin, Venous thromboembolism, Dyslipidemia, Dysglicemia

\footnotetext{
Correspondence: de.medeiros@terra.com.br

${ }^{1}$ Department of Gynecology and Obstetrics, Medical School, Federal

University of Mato Grosso, Cuiabá, MT 78055-728, Brazil

${ }^{2}$ Tropical Institute of Reproductive Medicine, Cuiabá, MT, Brazil
} 


\section{Background}

The prevalence of polycystic ovary syndrome (PCOS) ranges from $5 \%$ to $22 \%$ in women of reproductive age worldwide. It is associated with menstrual disturbances, hyperandrogenism, infertility, obesity and insulin resistance [1, 2]. Dyslipidemia, dysglycemia and metabolic syndrome (MetS) are also common [2, 3]. Adding evidences suggest that non-alcoholic fatty liver disease (NAFLD) exacerbates insulin resistance and predisposes patients with PCOS to an atherogenic status and the release of many proinflammatory, procoagulant and profibrogenic moderators [4]. Collectively, these data demonstrate that PCOS patients exhibit many conditions that could be tightly linked to future development of cardiovascular disease (CVD) and venous thromboembolism (VTE) (Table 1).

Despite the complex pathophysiological mechanisms and multiple phenotypes of PCOS, combined oral contraceptives (COCs) are the first-line option for the treatment of all women with PCOS not seeking to become pregnant, and they exert many beneficial effects in these women $[5,6]$. However, some deleterious metabolic effects have been demonstrated [7]. Concerns regarding the safety and the potential metabolic and cardiovascular risks of COCs in these patients persist [7-11]. This review has several purposes: (a) to consider the potential risks of isolated PCOS; (b) to estimate the potential additional risks of COC in patients with PCOS; (c) to examine why the use of COCs would be either beneficial or harmful for PCOS patients; (d) to focus on the noncontraceptive advantages/disadvantages of COC use in this syndrome; and (e), when possible, to suggest a specific formulation according to the patients' phenotype.

\section{Methods}

A comprehensive search and review of published studies on this topic and written in the English-language between

Table 1 Abnormal and subclinical conditions associated with risk of venous thromboembolism and cardiovascular disease in polycystic ovary syndrome

Central obesity

Systemic arterial hypertension

Hyperandrogenemia

Impaired glucose tolerance

Insulin resistance

Type II diabetes mellitus

Metabolic syndrome

Dyslipidemia

Nonalcoholic fatty liver disorder

Low-grade chronic inflammatory disease

Obstructive sleep apnea

Subclinical vascular disease
1982 and 2017 was performed using PubMed and the Cochrane database. When available, online searches of specialized journals were also used by adding adequate keywords. In addition, these databases were expanded by a manual search of references from the obtained articles. Older articles were also included as they provided basic and essential information. Keywords, alone or in combination, for the search included oral contraceptive, progestin, polycystic ovary syndrome, venous thromboembolism, cardiovascular disease and contraception. On the basis of the literature search, eligible studies that met the inclusion criteria of comparing head-to-head before and after data were identified. Ranges of collected data are given and pooled data are presented as median and first and third quartiles. Wilcoxon signed-ranks test for paired samples was used to compare before-after original data. $P$ value was set at 0.05 .

\section{Impact of combined oral contraceptives in the risk of VTE and CVD in PCOS patients}

An isolated diagnosis of PCOS increases the risk for VTE and CVD when compared with the general population [12-14]. VTE is considered the third most common cardiovascular disease with an overall annual incidence estimated at 1-2 events for every 1000 adults per year [15], has multiple risk factors and PCOS is a possible predisposing condition [13]. The likelihood of VTE among women with PCOS is reported to be 1.5-3 times higher than in non-PCOS controls [13, 16-19] and the risk can be modified by age, PCOS phenotype, oral contraceptive use, liraglutide [14] and comorbidities such as central obesity, diabetes mellitus type 2 (T2DM), or (MetS) [13]. Table 2

Table 2 Risks of venous/arterial diseases in PCOS women when compared with non-PCOS controls

\begin{tabular}{lll}
\hline Variable & Risk $(95 \% \mathrm{Cl})^{\text {a }}$ & Reference \\
\hline VTE & $1.55(1.10-2.19)$ & ST Bird et al., 2013 \\
CHD & $3.26(2.60-4.08)$ & EM Okoroh et al., 2012 \\
& $1.50(0.70-2.90)$ & S Wild et al., 2000 \\
& $1.25(1.07-1.47)$ & CG Solomon et al., 2002 \\
& $1.63(0.96-2.78)$ & SA Anderson et al., 2014 \\
& $1.27(1.10-1.46)$ & EM Okoroh et al., 2012 \\
& $1.44(1.13-1.84)$ & L Zhao et al., 2016 \\
Stroke & $2.80(1.10-7.10)$ & S Wild et al., 2000 \\
& $1.30(0.97-1.74)$ & CG Solomon et al., 2002 \\
& $1.61(0.94-3.315)$ & SA Anderson et al., 2014 \\
& $2.20(1.50-3.20)$ & T Matthesen et al., 2015 \\
& $2.02(1.47-2.76)$ & PCM de Groot et al., 2011 \\
& $4.24(1.96-9.17)$ & D Cibula et al., 2000 \\
\hline
\end{tabular}

VTE Venous thromboembolism, CHD Coronary heart disease, CI 95\% confidence interval

${ }^{a}$ Relative risk or hazard risk or odds ratio 
shows the size of potential factors of risk of VTE and CVD in PCOS non-users of COCs when compared with nonPCOS subjects [12, 13, 18, 20-25]. Regarding PCOS phenotype, the influence of higher androgen levels on the risk of VTE remains controversial [12, 13, 19, 23, 26, 27].

Since a diagnosis of PCOS alone might increase the risk of VTE and CVD, it is important to consider the possible existence of additional risk factors for these patients, including the use of COCs $[10,11,28]$. Simple disturbances in sex-steroid secretion, which are commonly seen in PCOS, has been associated with an increased risk of atherosclerosis and adverse cardiovascular events [18]. The proper use of COCs has also been associated with a twofold increased risk of fatal and nonfatal cardiovascular events $[28,29]$, which are perhaps related to endothelial dysfunction by altering the levels of nitric oxide, homocysteine, and angiotensin [30]. It must be emphasized that the association between the use of COCs and CVD has been demonstrated even in non-PCOS subjects, mainly among women who concomitantly smoke, who are over 35 years old or are users of third- or fourth-generation COCs that contain less androgenic progestin [31-35].

Three studies have examined the risk of VTE in users of COCs with PCOS (Table 3). One study using a combination of $35 \mu \mathrm{g}$ ethinylestradiol (EE) and $2 \mathrm{mg}$ cyproterone acetate (CPA) detected an odds ratio of 2.2 (95\% CI, 1.35-3.58) and 7.44 (95\% CI, 3.67-15.08) for the risk of VTE compared with users of other COCs and to nonusers, respectively [36]. One cross-sectional study included women who were 18-45 years old and who used any kind of $\mathrm{COC}$ demonstrated a protective association $(\mathrm{OR}=0.8 ; 95 \% \mathrm{CI}, 0.73-0.98)$ in PCOS users [13]. On the other hand, a Canadian study that included women who were 18-46 years old and used different criteria to diagnosis PCOS and different COCs containing $<35 \mu \mathrm{g}$ EE combined with second and third-generation progestins found a two fold increased risk for VTE in PCOS users $(\mathrm{RR}=2.14,95 \% \mathrm{CI}, 1.41-3.24)$, with a risk that was even higher in women with hyperandrogenism ( $\mathrm{HR}=$ 2.49; 95\% CI, 1.35-4.59) [18]. In summary, the results of these studies have limitations because they did not use

Table 3 Comparison of venous thromboembolism risks in PCOS users versus PCOS non-users of combined oral contraceptive

\begin{tabular}{lll}
\hline Variable & Risk $(95 \% \mathrm{Cl})^{\mathrm{c}}$ & Reference \\
\hline VTE & $2.58(1.60-4.18)^{\mathrm{a}}$ & HE Seaman et al., 2003 \\
& $7.44(3.67-15.08)^{\mathrm{b}}$ & HE Seaman et al., 2003 \\
& $0.80(0.73-0.98)$ & EM Okoroh et al., 2012 \\
& $2.14(1.41-3.24$ & ST Bird et al., 2013 \\
\hline
\end{tabular}

Cl 95\% confidence interval, VTE Venous thromboembolism

${ }^{a}$ Any combined oral contraceptive

${ }^{\mathrm{b} C o m b i n e d}$ oral contraceptive containing ethynilestradiol and cyproterone acetate

'Relative risk the same criteria for the diagnosis of PCOS, they compared subjects using a different combination of COCs and did not control for confounding variables such as PCOS phenotype, diet, exercise or body mass index.

\section{Potential benefits of combined oral contraceptives in PCOS}

Although, women with PCOS commonly present with hyperandrogenemia, central obesity, dysglycemia, dyslipidemia, and MetS, COCs are the preferred treatment intervention for women who do not wish to become pregnant. The reasons to choose COCs are sustained by several pharmacological benefits: a decrease in LH pulsatile secretion, a reduction in total and free circulating testosterone, an inhibition of $5 \alpha$-reductase enzyme activity, an increase in sex-hormone binding globulin (SHBG) levels, diminishing free testosterone levels (fT), an increase in insulin muscle sensitivity, menses regulation, elimination of the clinical signs of hyperandrogenism, and protection of the endometrium against neoplasms $[3,10]$. An ideal COC combination for PCOS women have not been established [6,37], although COC use is currently considered to be safe [6, 24, 38, 39]. Those patients with important metabolic risk factors should have an individualized approach [10, 40, 41]. The impact of COCs on the metabolic markers of PCOS was recently reviewed $[10,42]$.

\section{Sex-hormone binding globulin}

SHBG, glycoprotein produced by hepatocytes in the liver, binds to testosterone and estradiol with a high affinity. Its synthesis is increased by estrogen, thyroxin and decreased by androgens. Progesterone and progestins have variable androgenic effects and counter the beneficial estrogen effect on SHBG according to the androgenicity of each progestin. Low plasma SHBG levels which are seen in PCOS patients are considered an independent risk factor for the development of CVD [43-46], and NAFLD [47]. A few mechanisms may be involved in this association [48] and to increase SHBG concentrations in PCOS patients is necessary [49]. Since the relative androgenicity of progestin can be assessed by the measurement of plasma SHBG, this procedure may be useful in the clinical practice for assessing the estrogen/androgen balance of COCs. The estrogen components of COCs (e.g., ethinylestradiol and estradiol) induce hepatic SHBG production in a different intensity [50,51].

Concentrations of SHBG using a combined formulation that contains $35 \mu \mathrm{g}$ EE and $2 \mathrm{mg}$ of cyproterone acetate (CPA) for 3-6 months was reported in twelve studies [52-63]. The size of the SHBG increase found with this combination ranged from $37.31 \mathrm{nmol} / \mathrm{l}$ to $179.01 \mathrm{nmol} / \mathrm{l}$, with an average increase of $141.7 \mathrm{nmol} / \mathrm{l}$ $(p=0.002)$. It has been accepted that the combination 
induces the highest rise in SHBG and that is the most estrogenic COC in relation to its higher contents of estrogen and to the low androgenicity of CPA [56, 64]. Therefore, if the primary outcome is to increase SHBG, it was shown that $2 \mathrm{mg}$ CPA had no counteractive effect on the increase of SHBG levels induced by EE. Therefore this formulation is recommended, mainly for the treatment of PCOS patients with proved biochemical hyperandrogenism and menstrual disturbances.

Fifteen studies have reported on the SHBG increase with a COC combination containing of $30 \mu \mathrm{g}$ ethynilestradiol (EE) and $3 \mathrm{mg}$ drospirenone (DRSP) for six months. [52, 54, 62, 65-76]. The increase in SHBG concentrations with this combination ranged from $35.8 \mathrm{mmol} / \mathrm{l}$ to $140.8 \mathrm{mmol} / \mathrm{l}$, to an average increase of $105 \mathrm{mmol} / \mathrm{l}(p<0.001)$. Recently, two studies [76, 77] using $3 \mathrm{mg}$ DRSP with $20 \mu \mathrm{g}$ EE demonstrated an increase in SHBG levels from $40.0 \mathrm{mmol} / \mathrm{l}$ to $125.1 \mathrm{mmol} /$ 1 , an increment of $85 \mathrm{nmol} / \mathrm{l}(p=0.074)$. Only a single recent double-blind controlled trial reported a nonsignificant decrease of $0.5 \mathrm{mmol} / \mathrm{l}$ in the SHBG level with a pill that contained DRSP $(p>0.05)$ [78]. Therefore, regarding SHBG concentrations the benefits with the use of $20 \mu \mathrm{g}$ EE associated with $3 \mathrm{mg}$ DRSP are very low for clinical recommendation.

The impact of $2 \mathrm{mg}$ of chlormadinone acetate (CMA) combined with $30 \mu \mathrm{g}$ EE on SHBG concentrations was verified in six studies [67, 73, 75, 79-81]. SHBG levels increased from $38.8 \mathrm{mmol} / \mathrm{l}$ to $181.9 \mathrm{mmol} / \mathrm{l}$, average of $143.1 \mathrm{mmol} / \mathrm{l}(p=0.027)$. As SHBG secretion is not counteracted by CMA, which is bound to albumin rather than to SHBG, the current review support the knowledge that the combination is adequate for PCOS patients, primerly to those hyperandrogenemic with very low SHBG levels [82]. With a combination of $30 \mu \mathrm{g} \mathrm{EE}$ and $150 \mu \mathrm{g}$ desogestrel (DSG) in PCOS patients, SHBG blood levels were examined in five studies [52, 73, 74, 83, 84]. An increase in SHBG concentrations between $30 \mathrm{nmol} / \mathrm{l}$ and $123 \mathrm{nmol} / \mathrm{l}$ was detected, with an average of $+46.9 \mathrm{nmol} / \mathrm{l}$ $(p=0.043)$. A biphasic COC containing $40 \mu \mathrm{g} \mathrm{EE}$ for the first 7 days plus $25 \mu \mathrm{g}$ DSG and $30 \mu \mathrm{g}$ EE plus $125 \mu \mathrm{g}$ DSG for the subsequent 14 days increased SHBG from $43.2 \mathrm{nmol} / \mathrm{l}$ to $177.2 \mathrm{nmol} / \mathrm{l}$, increase of $134 \mathrm{nmol} / \mathrm{l}(p<$ 0.01) [55]. This combined COC containing DSG blocks the estrogen-mediated increase in SHBG more than other antiandrogenic progestins [74] and would not be the first choice for women with PCOS, mainly for those with biochemical hyperandrogenism.

A few studies reported on the use of COCs containing $30 \mu \mathrm{g}$ EE with $75 \mu \mathrm{g}$ gestodene (GSD) in PCOS patients. The results of two open clinical studies [73, 85] reported an increase in SHBG levels from $21.7 \mathrm{nmol} / \mathrm{l}$ to $109.2 \mathrm{nmol} / \mathrm{l}$, average increase of $65.4 \mathrm{nmol} / \mathrm{l}(p=0.049)$. Because the few number of studies and the high affinity of GSD for SHBG, no conclusion regarding the increase of SHBG could be done. Only one study [86] reported on SHBG levels modification in PCOS women using a combination of EE $35 \mu \mathrm{g} / \mathrm{NGM} 250 \mu \mathrm{g}$ and, in this study, SHBG changed from $32 \mathrm{nmol} / \mathrm{l}$ to $180 \mathrm{nmol} / \mathrm{l}$, an increase of $148 \mathrm{nmol} / \mathrm{l}(p<0.001)$ after 6 months of use. One other study evaluated the impact of EE30 $\mu \mathrm{g} / \mathrm{LNG}$ $150 \mu \mathrm{g}$ on SHBG and demonstrated an increase from $126 \mathrm{nmol} / \mathrm{l}$ to $195 \mathrm{nmol} / \mathrm{l}$, absolute increase of $69 \mathrm{nmol} / \mathrm{l}$ $(\mathrm{p}<0.001)$ [86]. When EE $20 \mu \mathrm{g}$ was combined to LNG $150 \mu \mathrm{g}$, the increase in SHBG varied from $57.7 \mathrm{nmol} / \mathrm{l}$ to $201 \mathrm{nmol} / \mathrm{l}$, absolute change of $143 \mathrm{nmol} / \mathrm{l} \quad(p<0.05)$ [87]. A synthesis of the impact of different COCs on SHBG levels is shown in Table 4.

\section{Total testosterone}

Testosterone $(\mathrm{T})$ is the most potent circulating androgen in women [50]. Approximately $65-70 \%$ of circulated $\mathrm{T}$ is bound and inactivated by SHBG, $30-35 \%$ is bound by albumin, and $1-3 \%$ represents the free $\mathrm{T}$ fraction [88]. The decrease of total and free testosterone is a primary objective for the use of COCs in PCOS patients. The benefit of COCs in hyperandrogenic PCOS patients is determined by two mechanisms: increasing SHBG for binding the $\mathrm{T}$ and decreasing the blood concentrations of the active free $\mathrm{T}$ molecule $[50,89]$. Regarding this matter, both the dose of the estrogen component and the androgenicity of the progestin must be considered. A summary of all studies published in this field is depicted in Table 4.

A combination of $35 \mu \mathrm{g}$ EE plus $2 \mathrm{mg}$ CPA in PCOS was reported on $\mathrm{T}$ concentrations at baseline and after six months of use in eleven studies [53, 55-60, 62, 63, 65, 90]. In all these studies, $\mathrm{T}$ concentrations showed a significant decrease from $79.53 \mathrm{ng} / \mathrm{dl}$ to $46.97 \mathrm{ng} / \mathrm{dl}$, an average decrease of $32.56 \mathrm{ng} / \mathrm{dl}(p=0.003)$. It can be concluded that in PCOS patients a decrease of about $30 \mathrm{ng} / \mathrm{dl}$ in the T levels would be expected with this combination. The results confirm the knowledge that the preparation is suitable for hyperandrogenemic PCOS women.

Using a combination of $30 \mu \mathrm{g}$ EE and $3 \mathrm{mg}$ DRSP, the decrease in $\mathrm{T}$ levels in PCOS patients was reviewed in fifteen studies [52, 62, 65-71, 73-77, 91]. In two publications, the extent of the modification of the $\mathrm{T}$ levels was not accurately verified $[52,75]$. Considering all thirteen studies in which was possible to calculate $\mathrm{T}$ changes, this formulation decreased $\mathrm{T}$ levels from $66.53 \mathrm{ng} / \mathrm{dl}$ to $48.9 \mathrm{ng} / \mathrm{dl}$, with an average decrease of $17.6 \mathrm{ng} / \mathrm{dl}(p<0.001)$. It seems that DRSP, even presenting a more prominent adrenal influence [54], significantly decrease total testosterone levels of PCOS users and could be chosen when patients present hypertension or hyperandrogenism. 
Table 4 Influence of different combined oral contraceptive formulations in the hyperandrogenemic biomarkers of polycystic ovary syndrome

\begin{tabular}{|c|c|c|c|c|c|}
\hline COC formulation & Number of studies & $\begin{array}{l}\text { Before } \\
\text { Md (1st - 3rd) }\end{array}$ & $\begin{array}{l}\text { After } \\
\text { Md (1st - 3rd) }\end{array}$ & $\Delta$ & $p^{*}$ \\
\hline \multicolumn{6}{|l|}{ SHBG $(\mathrm{nmol} / \mathrm{l})$} \\
\hline $\mathrm{EE} 35 \mu \mathrm{g} / \mathrm{CPA} 2 \mathrm{mg}$ & 12 & $37.3(32.7-52.9)$ & $179.0(122.1-235.7)$ & +141.7 & 0.002 \\
\hline EE $30 \mu \mathrm{g} / \mathrm{DRSP} 3 \mathrm{mg}$ & 15 & $35.8(29.9-45.3)$ & $140.8(62.8-180.0)$ & +105.0 & $<0.001$ \\
\hline $\mathrm{EE} 30 \mathrm{\mu g} / \mathrm{CMA} 2 \mathrm{mg}$ & 06 & $38.8(27.0-42.9)$ & 181.9 (140.0-217.9) & +143.1 & 0.027 \\
\hline EE $30 \mu \mathrm{g} / \mathrm{DSG} 75-150 \mu \mathrm{g}$ & 05 & $30.0(22.5-30.0)$ & $76.0(60-129)$ & +46.0 & 0.043 \\
\hline EE $30 \mu \mathrm{g} / \mathrm{GSD} 75 \mu \mathrm{g}$ & 02 & $21.7(17.5-26.0)$ & $109.2(87-131.0)$ & +65.4 & 0.049 \\
\hline \multicolumn{6}{|l|}{ Total T (ng/dl) } \\
\hline $\mathrm{EE} 35 \mu \mathrm{g} / \mathrm{CPA} 2 \mathrm{mg}$ & 11 & $79.5(31.2-100.0)$ & $46.9(30.0-66.1)$ & -32.5 & 0.003 \\
\hline EE $30 \mu \mathrm{g} / \mathrm{DRSP} 3 \mathrm{mg}$ & 15 & $66.5(60.0-86.4)$ & $48.9(39.0-55.0)$ & -17.6 & $<0.001$ \\
\hline EE 30 mg / CMA 2 mg & 05 & $78.0(73.4-84.1)$ & $41.9(45.8-60.3)$ & -36.1 & 0.043 \\
\hline EE $30 \mu \mathrm{g} / \mathrm{DSG} 75-150 \mu \mathrm{g}$ & 07 & $52.3(44.0-67.4)$ & $36.1(31.0-42.0)$ & -16.2 & 0.027 \\
\hline $\mathrm{EE} 30 \mu \mathrm{g} / \mathrm{GSD} 75 \mu \mathrm{g}$ & 02 & $72.7(64.4-81.0)$ & $51.8(47.5-56.0)$ & 19.9 & 0.179 \\
\hline \multicolumn{6}{|l|}{ Free $T(\mathrm{pmol} / \mathrm{l})$} \\
\hline EE $35 \mu \mathrm{g} / \mathrm{CPA} 2 \mathrm{mg}$ & 07 & $4.3(2.8-8.8)$ & $2.4(1.5-5.9)$ & -1.9 & 0.011 \\
\hline EE $30 \mu \mathrm{g} /$ DRSP 3 mg & 05 & $2.2(2.2-2.4)$ & $1.9(1.1-1.96)$ & -0.3 & 0.043 \\
\hline $\mathrm{EE} 30 \mu \mathrm{g} / \mathrm{CMA} 2 \mathrm{mg}$ & 05 & $7.8(6.1-7.9)$ & $4.2(3.8-4.7)$ & -3.6 & 0.043 \\
\hline $\mathrm{EE} 30 \mu \mathrm{g} / \mathrm{DSG} 150 \mu \mathrm{g}$ & 04 & $2.6(1.6-6.8)$ & $1.4(1.0-1.7)$ & -1.2 & 0.067 \\
\hline \multicolumn{6}{|l|}{ FAl (\%) } \\
\hline EE 35 rg / CPA 2 mg & 07 & $10.2(5.4-11.5)$ & $2.1(0.8-2.8)$ & -8.0 & 0.042 \\
\hline EE $30 \mu \mathrm{g} / \mathrm{DRSP} 3 \mathrm{mg}$ & 14 & $6.8(5.1-9.3)$ & $1.2(0.9-4.2)$ & -5.6 & 0.001 \\
\hline $\mathrm{EE} 30 \mathrm{\mu g} / \mathrm{CMA} 2 \mathrm{mg}$ & 05 & $9.4(7.9-9.7)$ & $0.9(0.9-0.94)$ & -8.5 & 0.043 \\
\hline EE $30 \mu \mathrm{g} / \mathrm{DSG} 75-150 \mu \mathrm{g}$ & 05 & $4.8(3.0-6.4)$ & $0.7(0.6-0.74)$ & -4.1 & 0.043 \\
\hline
\end{tabular}

COC combined oral contraceptive, $M d(1 s t-3 r d)$ median, first and third quartiles, $E E$ ethinylestradiol, CPA cyproterone acetate, DRSP drospirenone, CMA chlormadinone acetate, DSG desogestrel, GSD gestodene, SHBG sex-hormone binding globulin, $T$ testosterone, $F A l$ free androgen index $\mathrm{p}^{*}$ Wilcoxon signed- ranks test

The impact of a $30 \mu \mathrm{g}$ EE with $2 \mathrm{mg}$ CMA on T concentrations in PCOS patients was reported in five studies $[67,73,75,79,81]$. The significant decrease of $\mathrm{T}$ ranged from $78 \mathrm{ng} / \mathrm{dl}$ to $41.9 \mathrm{ng} / \mathrm{dl}$, with an average decrease of $36.1 \mathrm{ng} / \mathrm{dl}(p=0.043)$. Collectively, these results indicate that the combination can significantly decrease total testosterone levels in PCOS patients and could be a good option for PCOS patients with the hyperandrogenemic phenotype.

Seven studies reported changes in $\mathrm{T}$ concentrations in PCOS patients using a combination of $30 \mu \mathrm{g} E \mathrm{E}$ and $75 \mu \mathrm{g}$ DSG: [52, 55, 73, 83, 85, 92, 93]. With this preparation the decrease in T levels ranged from $52.3 \mathrm{ng} / \mathrm{dl}$ to $36.1 \mathrm{ng} / \mathrm{dl}$, with an average decrease of $16.21(p=0.027)$. In summary, it can be considered the use of COCs containing DSG in PCOS patients is a reasonable second option when a decrease in $\mathrm{T}$ levels is the main objective. Only two open clinical trials reported a combination of $30 \mu \mathrm{g}$ EE with $75 \mu \mathrm{g}$ GSD in PCOS patients [73, 85]. In these reports, $\mathrm{T}$ levels decreased from $72.7 \mathrm{ng} / \mathrm{dl}$ to $51.8 \mathrm{nmol} / \mathrm{l}$, average decrease of $19.9 \mathrm{nmol} / \mathrm{l} \quad(p=0.179)$. Because GSD competes with testosterone for SHBG sites, COCs containing this progestin should be avoided in PCOS patients, or at least considered a poor alternative.

\section{Free testosterone}

Approximately $1-3 \%$ of testosterone circulates as free $\mathrm{T}$ (fT). High fT in PCOS women are linked to low levels of SHBG and high levels of testosterone secretion [89]. The imprecision of the assays commonly used for fT measurement in women in the various studies limits some of the conclusions. Twenty one studies that reported on the impact that COCs had on the fT concentrations of PCOS patients were reviewed (Table 4). Seven of these studies have examined what the combination $35 \mu \mathrm{g} \mathrm{EE}$ with $2 \mathrm{mg}$ CPA had on the fT levels $[53,55,56,83,90$, $94,95]$. They have shown a decrease in free testosterone concentrations that ranged from $4.31 \mathrm{pg} / \mathrm{ml}$ to $2.4 \mathrm{pg} /$ $\mathrm{ml}$, with an average decrease of $1.9 \mathrm{pg} / \mathrm{ml}(p=0.011)$.

The impact that $30 \mu \mathrm{g}$ EE combined with $3 \mathrm{mg}$ DRSP had on $\mathrm{fT}$ concentrations was reported on five open clinical trials $[54,68,71,73,96]$ which reported that fT 
levels decreased from $2.2 \mathrm{pg} / \mathrm{ml}$ to $1.9 \mathrm{pg} / \mathrm{ml}$, with an average decrease of $0.3 \mathrm{pg} / \mathrm{ml}(p=0.043)$. Patients included in the study by Batukan and Muderris presented hirsutism but had not had a diagnosis of PCOS confirmed [71]. Different combinations of 30-40 $\mu \mathrm{g}$ EE with 25-125 mg DSG were reported to have affected the fT levels in PCOS patients $[55,73,89]$. With these combinations the decrease in $\mathrm{fT}$ levels ranged from $2.6 \mathrm{pg} / \mathrm{ml}$ to $1.4 \mathrm{pg} / \mathrm{ml}$, with an average of $-1.2 \mathrm{pg} / \mathrm{ml}(p=0.067)$. In five open trial $[67,73,75,79,81]$ and a case-control study [67] a combination of $30 \mu \mathrm{g}$ EE with $2 \mathrm{mg}$ CMA decreased fT from $7.8 \mathrm{pg} / \mathrm{l}$ to $4.2 \mathrm{pg} / \mathrm{ml}$ in PCOS patients, with an average decrease of $3.6 \mathrm{pg} / \mathrm{l}(p=0.043)$.

The combination of $30 \mu \mathrm{g}$ EE and $150 \mu \mathrm{g}$ DSG, evaluated in four studies [55, 73, 83, 92], decreased fT from $2.6 \mathrm{pg} / \mathrm{ml}$ to $1.4 \mathrm{pg} / \mathrm{ml}$, an average decrease of $1.2 \mathrm{pg} / \mathrm{ml}(\mathrm{p}=0.067)$, demonstrating that the preparation is not an adequate choice for treating PCOS patients. A combination of $30 \mu \mathrm{g}$ EE with $2 \mathrm{mg}$ DNG decreased fT from $1.4 \mathrm{pg} / \mathrm{ml}$ to $0.56 \mathrm{pg} / \mathrm{ml}(p<0.01)[50,97]$ and when $2 \mathrm{mg}$ DNG was combined with $2 \mathrm{mg}$ valerate estradiol (VE), fT decreased from 3.6 to $3.0 \mathrm{pg} / \mathrm{ml}(16 \%)$ after six months and from 3.6 to $2.5 \mathrm{ng} / \mathrm{ml}(22 \%)$ after twelve months $(p>0.05)$ [98], reflecting the lower impact of VE on the liver secretion of SHBG when compared with ethinylestradiol. Other COCs combining $20 \mu \mathrm{g}$. EE with $100 \mu \mathrm{g}$ levonorgestrel (LNG) and $30 \mu \mathrm{g}$ EE with $75 \mu \mathrm{g}$ GSD decreased fT levels from $1.56 \mathrm{pg} /$ $\mathrm{ml}$ to $0.63 \mathrm{pg} / \mathrm{ml}$ from $(p<0.01)$ and $2.0 \mathrm{pg} / \mathrm{ml}$ to $1.2 \mathrm{pg} / \mathrm{ml}$ $(p<0.05)$ [50,73], respectively. Only one study compared the effect of the combination of EE $35 \mu \mathrm{g} / \mathrm{NGM} 180$ $250 \mu \mathrm{g}$ in the fT levels in PCOS patients, fT decreased from $0.81 \mathrm{pg} / \mathrm{ml}$ to $0.35 \mathrm{pg} / \mathrm{ml}(p<0.05)[99]$.

\section{Free androgen index}

The FAI decrease in hyperandrogenemic women has been considered an independent predictor of improvement in endothelial function in these patients $[59,100]$. Thirty one studies, reported on the decrease of the FAI in PCOS patients (Table 4). The combination of $35 \mu \mathrm{g}$ EE with $2 \mathrm{mg}$ CPA was examined in seven studies [52, 54, 58-60, 62, 63]. Taking the results of these studies as a whole group, the FAI decreased from $10.2 \%$ to $2.1 \%$, with an average decrease of $8 \%(p=0.042)$. Using the combination of $30 \mu \mathrm{g}$ $\mathrm{EE}$ and $3 \mathrm{mg}$ of DRSP changes in the FAI levels were reported in fourteen studies $[52,54,62,65-67,69,70,72$, 74-77, 101]. With this combination, FAI decreased from $6.8 \%$ to $1.2 \%$, with an average decrease of $5.6 \%(p=0.001)$. This combination may be the preferred choice for PCOS patients with hyperandrogenemia, particularly whether associated with arterial hypertension or obesity. Prospective clinical trials remain needed though.

The effect of $2 \mathrm{mg}$ CMA and $30 \mu \mathrm{g}$ EE on FAI in PCOS patients was verified in five studies [67, 73, 75, 80, 81], and a significant decrease in FAI ranged from $9.4 \%$ to $0.92 \%$, with an average decrease of $8.5 \%(p=0.043)$. Collectively, these studies indicate that CMA does not counteract the liver's EE effect on the secretion of SHBG, assure a remarkable decrease in the FAI, and demonstrate that it is an adequate option for the treatment of hyperandrogenemic PCOS patients. In PCOS patients, a significant decrease in the FAI level was also reported in five studies with the COC combination of 25-150 $\mu$ g DSG and 30-40 $\mu \mathrm{g}$ EE $[55,61,74,92,93]$. The FAI decreased from $4.82 \%$ to $0.7 \%$, with an average decrease of $4.1 \%(p=0.043)$. Only one open clinical trial reported on the decrease of the FAI in PCOS patients using the COC combination of $75 \mu \mathrm{g}$ GSD and $30 \mu \mathrm{g}$ EE [85]. The FAI decreased from $13.3 \%$ to $2.2 \%$ $(p<0.05)$, after twelve months of follow-up; this study did not report on FAI decrease within six months, as was reported by the other studies analysed in this review. It may be concluded that at the moment this combination should not be a first-line choice for PCOS patients. Taken all studies united, it may be concluded that formulations containing CPA, CMA, and DRSP diminish the FAI by $80 \%-85 \%$ and should be preferred in PCOS patients.

\section{High-density lipoprotein-cholesterol}

The impact of COCs containing $35 \mu \mathrm{g}$ EE and $2 \mathrm{mg}$ CPA on the HDL-C levels in PCOS patients was reported in ten studies [53, 56, 59, 61, 63, 90, 94, 95, 100, 102]. Taking all of them, HDL-C levels significantly increased from $54.3 \mathrm{mg} / \mathrm{dl}$ to $61.5 \mathrm{mg} / \mathrm{dl}$, with an average increase of $7.3 \mathrm{mg} / \mathrm{dl}(p=$ 0.020). Only in three of these studies, HDL-C presented a nonsignificant increase $[53,59,94]$. In a single study HDL$\mathrm{C}$ did not change in PCOS patients who used this formulation [95]. COCs with DRSP significantly increased the HDL-C levels of PCOS patients from $59.5 \mathrm{mg} / \mathrm{dl}$ to $73.3 \mathrm{mg} / \mathrm{dl}$, average of $13.8 \mathrm{mg} / \mathrm{dl}(p=0.017)$ [54, 69, 72, 74, $91,96,100,101]$. In two particular studies, the HDL-C nonsignificantly increased by $5 \%[54,96]$ in DRSP preparations.

The influence of COCs containing $30 \mu \mathrm{g}$ EE and $2 \mathrm{mg}$ CMA on HDL-C concentrations in PCOS patients was examined in three studies only $[75,80,81]$. HDL-C increased from $51.1 \mathrm{mg} / \mathrm{dl}$ to $61.4 \mathrm{mg} / \mathrm{dl}$, average of $10.3 \mathrm{mg} / \mathrm{dl}(p=0.108)$. Three other studies $[61,74,103]$ reported an decrease in the HDL-C levels from $48.6 \mathrm{mg} /$ dl to $45.3 \mathrm{mg} / \mathrm{dl}$, average of $3.3 \mathrm{mg} / \mathrm{dl}(p=0.592)$ in PCOS patients who used COCs containing DSG. COCs with GSD [85] presented a nonsignificant decrease in the HDK-C, from $46.7 \mathrm{mg} / \mathrm{dl}$ to $45.9 \mathrm{mg} / \mathrm{dl}(p>0.05)$. Collectively, the results indicated that the increase in HDL-C with most COC preparations has clinical implications and should be considered a beneficial effect.

\section{Potential harms of combined oral contraceptives in polycystic ovary syndrome}

Considering the different phenotypes, many PCOS patients may present with a slight increase in blood pressure, 
be overweight or obese, and present with dysglycemia, dyslipidemia, MetS, NAFLD and elevated concentrations of chronic inflammatory process mediators. The use of different COC preparations may cause some harmful effects. Further, the phenotypes of women with PCOS should be additionally considered, and the decision to choose a specialized $\mathrm{COC}$ formulation should be made based on the estrogen type and dose and the progestin androgenicity $[50,104]$. Potential risks or disadvantages of COC use in PCOS women are considered according to the available data.

\section{Blood pressure}

Considering all formulations, fourteen studies reported on the influence of COCs on the systolic blood pressure (SBP) of PCOS patients $[52,59,72,74,75,77,80,81$, 99-103, 105]. Four studies reporting on $35 \mu \mathrm{g}$ EE with $2 \mathrm{mg}$ CPA use demonstrated a nonsignificant increase in the SBP, from $114.2 \mathrm{mmHg}$ to $116.19 \mathrm{mmHg}$, average increase of $2 \mathrm{mmHg}(p=0.144)[52,59,77,103]$ of women with PCOS. With the combination of $30 \mu \mathrm{g} E \mathrm{E}$ and $3 \mathrm{mg}$ DRSP, seven studies [52, 72, 74, 75, 77, 100, 101] reported a nonsignificant decrease in SBP, from $118.9 \mathrm{mmHg}$ to $118.4 \mathrm{mmHg}$, average decrease of $0.5 \mathrm{mmHg}(p=0.730)$. Only the Battaglia study demonstrated a significant rise in the SBP [72]. SBP diminished from $113.9 \mathrm{mmHg}$ to $112.2 \mathrm{mmHg}$, average decrease of $1.7 \mathrm{mmHg}(p=0.108)$ with the use of a COC preparation containing $30 \mu \mathrm{g} \mathrm{EE}$ and $2 \mathrm{mg}$ CMA [75, 80, 81]. Only one single study showed a nonsignificant increase in SBP in PCOS patients that used this preparation [80]. Oral contraceptives containing $30 \mu \mathrm{g}$ EE and 75-150 $\mu \mathrm{g}$ DSG was reported to increase SBP from $107.3 \mathrm{mmHg}$ to $108.2 \mathrm{mmHg}$, difference of $0.9 \mathrm{mmHg}(p=0.179)[74,105]$. Two recent publications reporting on the use of COC containing NGM did not find any modification in SBP [99, 105]. In summary, regarding SBP, the available data indicate that there are inconsistent results and nonsignificant changes in baseline SBP with the use of COCs, should not be expected, independent of the formulation. The possible beneficial effect of COC combination containing DRSP in the SBP was not proved in this review and this matter must be considered in future well-designed clinical trials.

The impact of $2 \mathrm{mg}$ CPA combined with $35 \mu \mathrm{g}$ EE on the diastolic blood pressure (DBP) was reported in five studies $[52,59,77,85,103]$ and demonstrated a nonsignificant increase in DBP from $75.9 \mathrm{mmHg}$ to $78.8 \mathrm{mmHg}$, an increase of $2.8 \mathrm{mmHg}(P=0.067)$. Therefore, choosing this formulation for PCOS patients with arterial hypertension might not be recommended. Seven studies examined the effect of COCs containing $30 \mu \mathrm{g}$ EE and $3 \mathrm{mg}$ DRSP on DBP $[52,72,74,75,77,100,101]$ and demonstrated a nonsignificant increase from $75 \mathrm{mmHg}$ to $75.7 \mathrm{mmHg}$, with an increment of $0.7 \mathrm{mmHg}(p=0.398)$. Interesting to note that two of these studies reported nonsignificant decreases of $0.5 \%$ [74] and 7.6\% [75] in the DBPs of PCOS patients with this combination. Nonsignificant decrease in DBP, from $74.4 \mathrm{mmHg}$ to $71.5 \mathrm{mmHg}$, decrease of $-2.9 \mathrm{mmHg}(p=0.102)$ was demonstrated with the use of COCs containing 2 mg CMA in PCOS patients $[75,80,81]$. Two studies evaluated the impact of COCs containing 75-150 $\mu \mathrm{g}$ DSG on the DBP of PCOS patients and found a nonsignificant increase from $69.0 \mathrm{mmHg}$ to $70.5 \mathrm{mmHg}$, increment of $1.5 \mathrm{mmHg}(p=$ $0.500)[74,103]$. Collectively, it could be concluded that COCs, independently of the combination, do not significantly influence the DBPs of PCOS patients who use them. However, pills with CMA might be preferred in PCOS patients with arterial hypertension.

\section{Total body weight}

The analysis of four RCTs revealed no difference in body weight gain after six months of COC use in non-PCOS women [106]. In addition, an observational study following $\mathrm{COC}$ users for more than two decades also did not demonstrate significant weight gain [107]. Eleven studies have examined 3 to 6 months impact of COCs on the body weight (BW) of PCOS patients $[59,63,67,69,74$, $79,81,84,92,96,102]$. Regarding the use of EE combined with CPA, two studies reported a nonsignificant increase from $69.6 \mathrm{~kg}$ to $69.8 \mathrm{~kg}$, increase of $0.2 \mathrm{~kg}(p=$ 0.754). Therefore, this formulation does not influence the BW of PCOS users.

The use of COC containing $30 \mu \mathrm{g}$ EE with $3 \mathrm{mg}$ DRSP resulted in a nonsignificant decrease in BW from $63.5 \mathrm{~kg}$ to $63.0 \mathrm{~kg}$, average decrease of $0.5 \mathrm{~kg}(p=0.465)$ $[67,69,74,96]$. The use of COCs containing $30 \mu \mathrm{g} \mathrm{EE}$ and $2 \mathrm{mg}$ CMA in PCOS patients was reported in three studies $[75,80,81]$ that resulted in a nonsignificant BW increase the range from $57.7 \mathrm{~kg}$ to $58.1 \mathrm{~kg}$, average increase of $0.4 \mathrm{~kg}(p=0.653)$. PCOS patients who used $30 \mu \mathrm{g}$ EE combined with $150 \mu \mathrm{g}$ DSG had a nonsignificant BW increase from $67 \mathrm{~kg}$ to $68.2 \mathrm{~kg}$, increase of $1.2 \mathrm{~kg}(p=0.900)[74,92]$. In summary, most of the different $\mathrm{COC}$ formulations did not promote significant weight gain in PCOS patients (Table 5). However, there is no strong evidence from the current data, it has been suggested that COC formulations with DRSP might be the right choice for obese PCOS women.

\section{Body mass index}

Thirteen studies evaluated the impact of COCs containing $35 \mu \mathrm{g}$ EE and $2 \mathrm{mg}$ CPA on the body mass index (BMI) of PCOS patients [52-55, 58-60, 62, 63, 94, 95, 100, 102]. Four studies demonstrated a significant decrease in the BMI of PCOS patients [94, 95, 100, 102], while other four studies showed a nonsignificant decrease in the BMI [52, 54, 55, 58]. Only six studies reported 
Table 5 Influence of different combined oral contraceptive formulations in the anthropometric parameters of polycystic ovary syndrome

\begin{tabular}{|c|c|c|c|c|c|}
\hline COC formulation & Number of studies & $\begin{array}{l}\text { Before } \\
\text { Md (1st - 3rd) }\end{array}$ & $\begin{array}{l}\text { After } \\
\text { Md (1st - 3rd) }\end{array}$ & $\Delta$ & $p^{*}$ \\
\hline \multicolumn{6}{|l|}{ BW } \\
\hline EE $35 \mu \mathrm{g} / \mathrm{CPA} 2 \mathrm{mg}$ & 02 & $69.6(67.7-80.2)$ & $69.8(67.1-72.3)$ & +0.2 & 0.754 \\
\hline EE $30 \mu \mathrm{g} / \mathrm{DRSP} 3 \mathrm{mg}$ & 04 & $63.5(60.1-66.2)$ & $63.0(61.8-65.1)$ & -0.5 & 0.465 \\
\hline $\mathrm{EE} 30 \mathrm{\mu g} / \mathrm{CMA} 2 \mathrm{mg}$ & 03 & $57.5(55.9-59.7)$ & $58.1(56.7-61.3)$ & +0.4 & 0.653 \\
\hline EE $30 \mu \mathrm{g} / \mathrm{DSG} 75-150 \mu \mathrm{g}$ & 02 & $67.0(66.1-67.9)$ & $68.2(67.5-70.1)$ & +1.2 & 0.900 \\
\hline \multicolumn{6}{|l|}{ BMI $\left(\mathrm{kg} / \mathrm{m}^{2}\right)$} \\
\hline EE $35 \mu \mathrm{g} / \mathrm{CPA} 2 \mathrm{mg}$ & 13 & $24.0(22.6-27.3)$ & $23.1(22.1-26.9)$ & -0.9 & 0.151 \\
\hline EE $30 \mu \mathrm{g} / \mathrm{DRSP} 3 \mathrm{mg}$ & 17 & $23.4(22.2-26.4)$ & $24.5(22.7-26.3)$ & +1.1 & 0.924 \\
\hline EE $30 \mu \mathrm{g} /$ CMA 2 mg & 05 & $22.5(22.2-23.3)$ & $22.7(22.5-23.4)$ & +0.2 & 0.138 \\
\hline EE $30 \mu \mathrm{g} / \mathrm{DSG} 75-150 \mu \mathrm{g}$ & 07 & $26.7(24.4-30.1)$ & $27.2(23.8-29.2)$ & +0.5 & 0.262 \\
\hline \multicolumn{6}{|l|}{$W C(\mathrm{~cm})$} \\
\hline EE $30 \mu \mathrm{g} / \mathrm{DRSP} 3 \mathrm{mg}$ & 03 & $76.7(74.0-79.4)$ & $77.6(75.4-79.2)$ & +0.9 & 0.810 \\
\hline $\mathrm{EE} 30 \mu \mathrm{g} / \mathrm{CMA} 2 \mu \mathrm{g}$ & 02 & $78.3(78.0-78.7)$ & $72.2(77.0-77.4)$ & -1.1 & 0.089 \\
\hline EE $30 \mu \mathrm{g} / \mathrm{NGM} 180-250 \mu \mathrm{g}$ & 03 & $80.3(63.3-97.3)$ & $79.7(63.7-95.7)$ & -0.6 & 0.179 \\
\hline \multicolumn{6}{|l|}{ WHR } \\
\hline $\mathrm{EE} 35 \mu \mathrm{g} / \mathrm{CPA} 2 \mathrm{mg}$ & 07 & $0.80(0.74-0.91)$ & $0.79(0.74-0.88)$ & -0.01 & 0.179 \\
\hline EE $30 \mu \mathrm{g} /$ DRSP 3 mg & 12 & $0.78(0.76-0.81)$ & $0.75(0.74-0.81)$ & -0.03 & 0.241 \\
\hline EE $30 \mu \mathrm{g} / \mathrm{CMA} 2 \mathrm{mg}$ & 02 & $0.73(0.51-0.095)$ & $0.78(0.75-0.81)$ & -0.05 & 0.317 \\
\hline EE $30 \mu \mathrm{g} / \mathrm{DSG} 75-150 \mu \mathrm{g}$ & 04 & $0.81(0.75-0.82)$ & $0.80(0.75-0.82)$ & -0.01 & 0.654 \\
\hline EE $30 \mu \mathrm{g} / \mathrm{NGM}$ 180-250 $\mu \mathrm{g}$ & 02 & $0.80(0.74-0.86)$ & $0.78(0.75-0.81)$ & -0.02 & 0.317 \\
\hline \multicolumn{6}{|l|}{ FM (kg) } \\
\hline EE $30 \mu \mathrm{g} / \mathrm{DRSP} 3 \mathrm{mg}$ & 03 & $21.0(19.20-22.0)$ & $22.9(20.9-24.8)$ & +1.9 & 0.108 \\
\hline
\end{tabular}

COC combined oral contraceptive, $M d(1 s t-3 r d)$ median, first and third quartiles, $B W$ body weight, $B M I$ body mass index, WC waist circumference, $W H R$ waist-hip ratio, FM fat mass, EE ethinylestradiol, CPA cyproterone acetate, DRSP drospirenone, CMA chlormadinone acetate, DSG desogestrel, NGM norgestimate $\mathrm{p}^{*}$ Wilcoxon signed- ranks test

a nonsignificant increase in the BMI of PCOS patients who used CPA [53, 59, 60, 62, 63, 67]. Collectively, these studies demonstrated a slight decrease in the BMI of PCOS patients who use EE combined with CPA, from $24 \mathrm{~kg} / \mathrm{m}^{2}$, to $23.1 \mathrm{~kg} / \mathrm{m}^{2}$ a decrease of $0.9 \mathrm{~kg} / \mathrm{m}^{2}(p=0.151)$. BMI changes in PCOS users of COCs containing $30 \mu \mathrm{g} \mathrm{EE}$ and $3 \mathrm{mg}$ DRSP were reported on seventeen clinical studies [52, 54, 62, 6569, 72, 74-77, 91, 96, 100, 101]. Two studies reported a significant BMI decrease in PCOS patients $[74,100]$ and nine studies found a nonsignificant decrease $[52,54,65$, $66,69,72,75,79,96]$. Only six studies reported a nonsignificant increase in the BMI of PCOS patients who used COCs containing DRSP $[62,67,69,76,77,101]$. Collectively, these studies demonstrated a nonsignificant small increase in the BMI from $23.4 \mathrm{~kg} / \mathrm{m}^{2}$ to $24.47 \mathrm{~kg} / \mathrm{m}^{2}$, an increase of $1.02 \mathrm{~kg} / \mathrm{m}^{2}(p=0.924)$ with the use of COC with DRSP.

BMI changes in PCOS patients using a combination of EE with CMA was reported in five studies $[67,75,79-81]$. Four of the studies reported a nonsignificant BMI increase [67, 79-81]. Only the study by Yildizhan found a nonsignificant decrease of $0.5 \%$ [75]. Taken together, with this combination the BMI increased from $22.52 \mathrm{~kg} / \mathrm{m}^{2}$ to $22.7 \mathrm{~kg} / \mathrm{m}^{2}$, an increase of $0.18 \mathrm{~kg} / \mathrm{m}^{2}(p=0.138)$. Therefore, this COC does not modify the BMI of PCOS patients who use it. DSG combined with EE was shown to decrease BMI in a nonsignificant range in seven studies [52, 55, 74, 92, 103, 105, 108]. Either nonsignificant or significant increases of $1.1 \%$ and $5.3 \%$ in the BMIs of PCOS patients was also shown in two studies [74, 103]. Seven studies with EE combined with DSG demonstrated that BMI increased from $26.7 \mathrm{~kg} / \mathrm{m}^{2}$ to $27.2 \mathrm{~kg} / \mathrm{m}^{2}$, an increase of $0.5 \mathrm{~kg} / \mathrm{m}^{2}(p=0.262)$. GSD associated with EE induced a nonsignificant increase in the BMI from $26.2 \mathrm{~kg} / \mathrm{m}^{2}$ to $26.5 \mathrm{~kg} / \mathrm{m}^{2}$ in a single study $(p>0.05)$ [85]. Recently, it was shown that COC with NGM decreased the BMI from $32.6 \mathrm{~kg} / \mathrm{m}^{2}$ to $32.5 \mathrm{~kg} / \mathrm{m}^{2}$ ( $\mathrm{p}>0.05$ ) [99]. In conclusion, the current studies did not endorse the idea that COCs increase BMI (Table 6).

\section{Waist circumference}

Possible waist circumference (WC) changes with the use of COCs in PCOS patients were examined in nine 
Table 6 Influence of different combined oral contraceptive formulations in the carbohydrate metabolism biomarkers of polycystic ovary syndrome

\begin{tabular}{|c|c|c|c|c|c|}
\hline COC formulation & Number of studies & $\begin{array}{l}\text { Before } \\
\text { Md (1st - 3rd) }\end{array}$ & $\begin{array}{l}\text { After } \\
\text { Md (1st - 3rd) }\end{array}$ & $\Delta$ & $p^{*}$ \\
\hline \multicolumn{6}{|l|}{ Glucose (mg/dl) } \\
\hline EE 35 mg / CPA 2 mg & 12 & $86.6(81.0-92.0)$ & $85.6(84.3-91.9)$ & -1.0 & 0.514 \\
\hline EE 30 mg / DRSP 3 mg & 10 & $84.4(78.7-91.2)$ & $85.7(80.6-90.6)$ & +1.3 & 0.998 \\
\hline EE $30 \mu \mathrm{g} /$ CMA $2 \mu \mathrm{g}$ & 2 & $86.0(84.5-87.5)$ & $81.8(80.5-83.1)$ & -4.2 & 0.010 \\
\hline EE $30 \mu \mathrm{g} / \mathrm{DSG} 75-150 \mu \mathrm{g}$ & 5 & $84.5(81.3)-88.9)$ & $85.2(81.9-88.0)$ & +0.7 & 0.892 \\
\hline \multicolumn{6}{|l|}{ Insulin ( $\mu U \mathrm{Ul} / \mathrm{ml})$} \\
\hline EE 35 rg / CPA 2 mg & 11 & $17.9(10.8-22.8)$ & $17.1(10.0-18.6)$ & -0.8 & 0.213 \\
\hline EE 30 mg / DRSP 3 mg & 08 & $13.9(11.3-18.1)$ & $12.1(10.1-18.5)$ & -1.8 & 0.865 \\
\hline EE 30 mg / CMA 2 mg & 03 & $7.3(5.2-9.4)$ & $7.8(6.1-9.5)$ & +0.5 & 0.285 \\
\hline EE $30 \mu \mathrm{g} / \mathrm{DSG} 75-150 \mu \mathrm{g}$ & 04 & $15.7(13.0-19.0)$ & $17.1(13.1-22.1)$ & +1.4 & 0.144 \\
\hline EE $30 \mu \mathrm{g} / 180-250 \mu \mathrm{g} \mathrm{NGM}$ & 02 & $8.9(7.6-10.2)$ & $9.1(7.2-11.0)$ & +0.2 & 0.788 \\
\hline \multicolumn{6}{|l|}{ C-peptide (mg/dl) } \\
\hline EE 35 rg / CPA 2 mg & 03 & $2.6(2.0-3.2)$ & $3.0(2.9-3.9)$ & +0.4 & 0.179 \\
\hline EE 30 mg / DRSP 3 mg & 03 & $1.2(0.7-1.7)$ & $1.3(0.7-1.9)$ & +0.1 & 0.654 \\
\hline EE $30 \mu \mathrm{g} / \mathrm{DSG} 75-150 \mu \mathrm{g}$ & 02 & $1.6(1.5-1.7)$ & $2.4(2.0-2.8)$ & +0.8 & 0.179 \\
\hline \multicolumn{6}{|l|}{ HOMA-IR } \\
\hline EE 35 rg / CPA 2 mg & 09 & $3.6(2.0-4.4)$ & $2.2(1.8-3.9)$ & -1.4 & 0.213 \\
\hline EE 30 mg / DRSP 3 mg & 10 & $3.1(2.2-3.7)$ & $2.8(2.5-3.8)$ & -0.3 & 0.593 \\
\hline EE $30 \mu \mathrm{g} /$ CMA 2 mg & 03 & $1.6(1.2-2.0)$ & $1.6(1.3-2.0)$ & 0 & 0.592 \\
\hline EE $30 \mu \mathrm{g} / \mathrm{DSG} 75-150 \mu \mathrm{g}$ & 03 & $3.0(2.3-3.7)$ & $2.6(2.2-3.0)$ & -0.4 & 0.285 \\
\hline \multicolumn{6}{|l|}{$\mathrm{HbA1C}(\%)$} \\
\hline EE 35 mg / CPA 2 mg & 04 & $5.0(4.6-5.4)$ & $5.1(4.7-5.6)$ & +0.1 & 0.422 \\
\hline EE 30 mg / DRSP 3 mg & 02 & $3.5(2.7-4.3)$ & $3.5(1.7-7.3)$ & 0 & 0.653 \\
\hline
\end{tabular}

COC combined oral contraceptive, Md (1st - 3rd) median, first and third quartiles, HOMA-IR homeostatic model assessment for insulin resistance, HbA1C glycated hemoglobin, EE ethinylestradiol, CPA cyproterone acetate, DRSP drospirenone, CMA chlormadinone acetate, DSG desogestrel, NGM norgestimate p* Wilcoxon signed- ranks test

studies $[52,59,69,77,80,81,93,99,109]$. One study reported a nonsignificant increase of $0.1 \mathrm{~cm}(76.3 \mathrm{~cm}$ to $76.4 \mathrm{~cm}$ ) in the WC [54], when a COC formulation containing CPA was used. A combination of EE with DRSP also showed nonsignificant increases from $76.7 \mathrm{~cm}$ to $77.6 \mathrm{~cm}$, increment of $0.9 \mathrm{~cm}(p=0.810)$ in the WC of PCOS patients, [52, 69, 77]. COCs containing EE and CMA showed a nonsignificant decrease in the WC in PCOS users, which was from 78.3 to $77.1 \mathrm{~cm}$, decrease of $1.1 \mathrm{~cm}(p=$ $0.179)[80,81]$. The combination of $30 \mu \mathrm{g}$ EE plus 180 $250 \mu \mathrm{g}$ NGM showed to diminish WC from $80.3 \mathrm{~cm}$ to $79.7 \mathrm{~cm}(p=0.179)[93,99,109]$. The analysis of nine studies reporting on the influence of different COCs in the WC allowed to conclude that COCs do not change significantly this anthropometric parameter. This conclusion confirms the findings of a recent systematic review [107].

\section{Waist-hip ratio}

Seven studies examined the influence of $35 \mu \mathrm{g}$ EE with $2 \mathrm{mg}$ CPA on the waist-hip ratio (WHR) of PCOS patients $[52-55,60,100,102]$. Five studies showed no modification of the WHR with this combination, and two studies showed a nonsignificant decrease in the WHR [53, 102]. The WHR changed from $0.8 \mathrm{~cm}$ to $0.79 \mathrm{~cm}(\mathrm{p}=0.179)$ when all studies were considered for calculation. Therefore, COCs with CPA had no impact on the WHR of PCOS patients and can be used in patients with an abnormal WHR. The influence of COCs containing $30 \mu \mathrm{g} \mathrm{EE}$ and $3 \mathrm{mg}$ DRSP in the WHR of PCOS patients were examined in twelve studies [52, 54, 65, 66, 69, 70, 72, 75-77, 100, 101]. Nonsignificant decrease from $0.78 \mathrm{~cm}$ to $0.75 \mathrm{~cm}$ was found, average decrease of $0.03 \mathrm{~cm}(p=0.241)$. It can also be concluded that COCs containing DRSP has little to no effect on the WHR of PCOS patients.

The influence of COCs containing $30 \mu \mathrm{g}$ EE and $2 \mathrm{mg}$ CMA on the WHR of PCOS patients were examined in only two studies $[75,79]$ that demonstrated an increase from 0.73 to 0.78 in this ratio $(p=0.317)$. The impact of $30 \mu \mathrm{g}$ EE combined with 75-150 $\mu \mathrm{g}$ DSG was reported 
in four clinical studies $[52,55,92,93]$ and the WHR decreased from 0.81 to $0.80(p=0.654)$; therefore, it can be concluded that COCs containing either CMA or DSG also have no impact on the WHR of PCOS users. Formulation containing $30 \mu \mathrm{g}$ EE and 180-250 $\mu \mathrm{g}$ NGM showed a nonsignificant decrease in WHR, from 0.80 to 0.78 ( $p=$ $0.317)$ in two studies $[99,109]$. Collectively, COCs use by PCOS patients do not modify the WHR (Table 5).

\section{Fat mass}

The influence of COC use in the fat mass (FM) of PCOS women have been examined in seven studies $[69,79,91$, $96,102,106,110]$. FM $(\mathrm{kg})$ was reported to increase in PCOS patients who used $30 \mu \mathrm{g}$ EE with $3 \mathrm{mg}$ DRSP in three studies $[69,91,96]$. This increase was from $21 \mathrm{~kg}$ to $22.9 \mathrm{~kg}$, increase of $1.9 \mathrm{~kg}(p=0.108)$. A nonsignificant decrease of $0.16 \%$ was also reported in a single study [110]. Changes in FM were not reported in PCOS patients who used other COC formulations [79, 102]. The percentage of body fat mass (FM\%) exhibited a nonsignificant decrease of $0.4 \%$ in a single study [102]. A significant decrease of $6.5 \%$ was found in another study [69], but the FM \% was significantly increased by $9 \%$ in an earlier publication [96]. Currently, it is not possible to make any conclusive statement regarding the effect of COCs on the body fat change in PCOS patients, although long-term $\mathrm{COC}$ use tends to reduce abdominal fat depots [107].

\section{Carbohydrate metabolism}

The effect of COCs on the carbohydrate metabolism of non-PCOS subjects has been associated with increased fasting glucose, increased fasting insulin and abnormal oral glucose tolerance test (OGTT). However, the results are inconsistent. This section examines the impact of different $\mathrm{COC}$ combinations on the carbohydrate metabolism of PCOS users. A summary of the current data is provided in Table 6.

\section{Fasting glucose}

Fasting glucose, in PCOS patients who used $35 \mu \mathrm{g}$ EE with $2 \mathrm{mg} \mathrm{CPA}$, was described in twelve studies published between 1990 and 2016. Had a nonsignificant increase in fasting glucose levels ranged from $0.57 \%$ to $2.57 \%$, average of $1.2 \%$, demonstrated in seven studies $[56,58-60,90,102,105]$. Three clinical trials reported no change in fasting glucose with this preparation [52, 54,63 ], and a nonsignificant decrease of $4.0 \%$ [55] and a significant decrease of $8.0 \%$ [53] were also detected. As a whole group, the studies demonstrated that fasting glucose levels decreased from $86.6 \mathrm{mg} / \mathrm{dl}$ to $85.5 \mathrm{mg} / \mathrm{dl}(p$ $=0.514$ ) in PCOS users of COC with CPA. A recent study examining a three-hour OGTT response found a nonsignificant decrease from 460.6 to $450.8(p=0.359)$ in the glucose area under the curve (AUC) [105]. Collectively, these findings indicate that there is a nonsignificant increase, or even a slight decrease, in the fasting glucose levels of PCOS patients who used COCs containing CPA.

With the use of COCs containing DRSP, the fasting glucose levels of PCOS patients presented nonsignificant increase in four clinical studies [69, 72, 96, 110]. In another three studies, the fasting glucose decreased in a nonsignificant way [52, 66, 101]. However, fasting glucose levels decreased significantly in two other reports $[74,100]$, but in one single study, fasting glucose levels did not change with COCs containing DRSP [54]. Collectively, these ten studies showed a nonsignificant increase of fasting glucose from $84.4 \mathrm{mg} / \mathrm{dl}$ to $85.7 \mathrm{mg} / \mathrm{dl}$ $(p=0.998)$. In addition, three studies reported the glucose AUC after OGTT in PCOS patients who used COCs with DRSP. Two of these studies showed nonsignificant increases of $0.4 \%$ [72] and 9\% [110]; the other study demonstrated a significant increase from 419.8 to $467.8(p=0.005)$ [100]. At this moment, it is not possible to make conclusive statement regarding the impact of COCs containing DRSP on the glucose metabolism of PCOS users, but the current studies indicate that there is no additional harm.

Fasting glucose changes with the use of COCs containing CMA in PCOS patients were reported to decrease it from $86 \mathrm{mg} / \mathrm{dl}$ to $81.8 \mathrm{mg} / \mathrm{dl}$, decrease of $4.2 \mathrm{mg} / \mathrm{dl}(p=$ $0.010)[80,81]$. In five studies $[52,55,74,92,103]$ the use of COC preparations with DSG showed a nonsignificant increase in fasting glucose ranging from $84.5 \mathrm{mg} / \mathrm{dl}$ to $85.2 \mathrm{mg} / \mathrm{dl}$, an increase of $0.7 \mathrm{mg} / \mathrm{dl}(p=0.892)$. In conclusion, the use of COCs with DSG does not significantly modify the fasting glucose levels of PCOS patients. The combination of EE $33 \mu \mathrm{g}$ and NGM 180$250 \mu \mathrm{g}$ in PCOS women showed a nonsignificant decrease in the fasting glucose from $86.2 \mathrm{mg} / \mathrm{dl}$ to $85.1 \mathrm{mg} / \mathrm{dl}(p=0.179)[99,109,111]$. In summary, COCs containing CMA, DSG, and NGM also do not modify the fasting glucose levels in PCOS users.

\section{Fasting insulin}

Eleven prospective clinical studies have reported on the impact of COCs containing CPA in the fasting insulin levels of PCOS patients. Four studies reported a nonsignificant decrease $[53,59,60,102]$, but two reported significant decreases $[94,95]$. Nonsignificant increases were also reported with the use of CPA $[52,55,63,100]$. A single study did not demonstrate any modification in the fasting insulin of PCOS patients who used COCs containing CPA [90]. Regarding fasting insulin levels, collectively, these studies demonstrated that insulin decreased from $17.9 \mu \mathrm{UI} / \mathrm{ml}$ to $17.1 \mu \mathrm{UI} / \mathrm{ml}(p=0.213)$. Therefore, two studies reported significant decreases in 
the insulin AUC after OGTT in PCOS users of CPA [59, 100]. Additionally, these studies strongly indicated that COCs containing CPA do not worsen insulin metabolism in PCOS patients.

The impact of $30 \mu \mathrm{g}$ EE with $3 \mathrm{mg}$ DRSP on the fasting insulin of PCOS patients was reported in eight studies. Six studies reported nonsignificant increases [52, 54, $69,72,78,96]$, one single study reported an astonishing increase of $241 \%$ in the fasting insulin levels with the use of DRSP, but this study had a very small sample size and a very low power [96], and another study reported a nonsignificant decrease [101]. Significant decreases in fasting insulin were also demonstrated with EE plus DRSP $[78,100]$. In addition, eight studies have shown that fasting insulin decreased from $13.9 \mu \mathrm{UI} / \mathrm{ml}$ to 12.1 $\mu \mathrm{UI} / \mathrm{ml}$, a decrease of $1.8 \mu \mathrm{UI} / \mathrm{ml}(p=0.865)$. One study also reported a very small and clinically nonsignificant decrease of the insulin AUC after OGTT [72]. However, a clinically significant decrease of $20.3 \%$ in the insulin AUC was recently reported [100]. On the other hand, a nonsignificant increase of $31 \%$ in the AUC was also found [96]. In summary, COCs with DRSP can be used safely in PCOS patients and do not appear to cause any additional disturb in the fasting insulin.

The use of COCs containing $30 \mu \mathrm{g}$ EE with $2 \mathrm{mg}$ CMA has shown inconsistent results regarding fasting insulin levels. Both, a nonsignificant decrease [79] and a nonsignificant increase $[80,81]$ have been reported. Considering all three studies, the insulin levels increased from $7.3 \mu \mathrm{UI} / \mathrm{ml}$ to $7.8 \mu \mathrm{UI} / \mathrm{ml}(p=0.285)$. COCs containing $30 \mu \mathrm{g}$ EE and 75-150 DSG increased the insulin levels of PCOS patients from $15.7 \mu \mathrm{UI} / \mathrm{ml}$ to $17.1 \mu \mathrm{UI} /$ $\mathrm{ml}$, an increase of $1.4 \mu \mathrm{UI} / \mathrm{ml}(p=0.144)$ [52, 55, 74, 92]. It can be concluded that COCs containing DSG tend to increase the fasting insulin levels of PCOS users. The use of $30 \mu \mathrm{g}$ EE and 180-250 $\mu \mathrm{g}$ NGM increased insulin levels from $8.9 \mu \mathrm{UI} / \mathrm{ml}$ to $9.1 \mu \mathrm{UI} / \mathrm{ml}(p=0.788)$ in two studies $[99,111]$. Collectively, COCs with CMA, DSG, and NGM progestins promote a small and nonsignificant increase in the fasting insulin levels of PCOS patients.

\section{C-peptide}

The influence of COCs containing $35 \mu \mathrm{g} E$ and $2 \mathrm{mg}$ CPA in the C-peptide concentrations of PCOS patients have been reported in a few studies, and the results are inconsistent. A significant increase in C-peptide of $28.9 \%$ was previously reported using this preparation [60]. Either a nonsignificant increase [55] or no change [54] in C-peptide levels have also been found. Taking these three studies together, C-peptide levels increased $0.4 \mathrm{ng} / \mathrm{ml}$, from $2.6 \mathrm{ng} / \mathrm{ml}$ to $3.0 \mathrm{ng} / \mathrm{ml}(p=0.179)$ in PCOS patients with this combination. The effect of COCs with DRSP in the C-peptide levels of PCOS patients are also unclear: a nonsignificant decrease of $4.7 \%$
[72] and nonsignificant increases of 3\% [54] and 10\% [110] were reported. In fact, COCs with DRSP increased C-peptide from $1.2 \mathrm{ng} / \mathrm{ml}$ to $1.3 \mathrm{ng} / \mathrm{ml}$ in these three studies $(p=0.654)$. The AUC of the C-peptide was shown to increase by a nonsignificant $11.6 \%$ in PCOS patients who used COCs with DRSP [110].

A formulation containing CMA with EE showed a nonsignificant decrease in the C-peptide levels from $4.43 \mathrm{ng} / \mathrm{ml}$ to $4.35 \mathrm{ng} / \mathrm{ml}(p=0.317)$ [75] and COC with DSG presented an nonsignificant increase of $0.7 \mathrm{ng} / \mathrm{ml}$, from $1.63 \mathrm{ng} / \mathrm{ml}$ to $2.38 \mathrm{ng} / \mathrm{ml}(\mathrm{p}=0.179)$ [55, 93]. Thus, the results of these studies do not allow for any conclusive statement regarding the effect of all COC preparations on the C-peptide concentrations of PCOS patients. The impact of these preparations on the $\mathrm{C}$-peptide concentrations must be specifically re-examined.

\section{Homeostatic model assessment-IR}

HOMA-IR changes in PCOS patients who used COCs containing CPA were reported in nine prospective studies. A nonsignificant decrease in the HOMA-IR index, was demonstrated in five of those studies $[54,59,62$, $100,103]$, a significant decrease in two $[94,95]$ and a nonsignificant increases in other two studies and CPA [52, 63]. Collectively, HOMA-IR decreased from 3.6 to $2.2(p=0.213)$ in PCOS users of COCs with this formulation. In summary, regarding HOMA-IR, COCs with CPA can be safely used in PCOS patients and might improve insulin resistance.

With the combination of $30 \mu \mathrm{g}$ EE and $3 \mathrm{mg}$ DRSP changes in the HOMA-IR of PCOS patients wer reported in ten studies. Five of then showed a nonsignificant increase $[52,54,63,66,69]$; one single study showed a significant increase, and another one [72] demonstrated a significant decrease of 31\% [100]. Two studies reported a nonsignificant decrease in the HOMA-IR with DRSP pill $[74,75]$ and, in addition, no modification of the HOMAIR was shown in a recent double-blind RCT [101]. Collectively, all ten studies demonstrated that HOMA-IR had a nonsignificant small decrease from 3.1 to $2.8(p=0.593)$ with the use of DRSP preparations. Therefore, the data regarding the impact of a pill with DRSP on the HOMA-IR are inconsistent, but not harmful.

The HOMA-IR was shown to increase from 1.58 to 1.63 $(p=0.592)$ in PCOS patients who used COCs containing $30 \mu \mathrm{g}$ EE and $3 \mathrm{mg}$ CMA [75, 80, 81]. One single study showed a nonsignificant decrease in this index with this preparation [75]. COCs containing DSG showed either an increase [74] or a decrease [52, 108] in the HOMA-IR of PCOS patients. The analysis of these three studies demonstrated that HOMA-IR decreased from 3.0 to 2.6 ( $p=$ 0.285 ) with pill containing DSG. In summary, COCs containing most progestins present inconsistent effects in the 
HOMA-IR of PCOS patients and more studies are required to take a definitive conclusion.

\section{Glycated haemoglobin}

Glycated hemoglobin (HbA1C) may be a better indicator of overall glycemia status in both non-PCOS [112] and PCOS individuals [113]. HbA1C levels have been reported to be increased in PCOS patients when compared with non-PCOS controls [114-116]. Some guidelines suggest that the measurement of HbA1C may be an acceptable option to screen for dysglycemia $[5,117]$ and to discriminate patients in whom OGTT would be appropriated [2]. Currently, changes in the HbA1C levels of PCOS patients using COCs were reported in a few studies. Two studies did not show any modification in HbA1C levels with EE plus CPA preparation [54, 100]. Otherwise, two prospective trials showed a nonsignificant increase in the HbA1C levels of PCOS patients who used this preparation [58,61]. Mutually, these studies have demonstrated a nonsignificant increase in $\mathrm{HbA1C}$, from 5.0 to $5.1(p=0.422)$ with CPA pill HbA1C levels maintained unchanged with the use of COCs containing $\mathrm{EE} 30 \mu \mathrm{g}$ and DRSP $3 \mathrm{mg}$ : from 3.5 to 3.5 after six months $(p=0.653)$. Therefore, no definitive conclusion can be drawn at this time regarding the impact of COCs containing CPA or DRSP on the HbA1C in PCOS patients who used these preparations for six months.

\section{Lipid metabolism}

As dyslipidemia is common in PCOS women, it is recommended that lipid measurement is performed before any therapeutic intervention. The impact of different COC preparations on the lipid levels of non-PCOS subjects have been extensively investigated. This section describes the main discoveries of observational and randomized and non-randomized controlled trials currently available for analysis regarding the effect of different COC combinations on the lipids of PCOS patients. Table 7 illustrates a summary of the current discoveries.

\section{Total cholesterol}

The influence of COCs containing $35 \mu \mathrm{g}$ EE with $2 \mathrm{mg}$ CPA on the total cholesterol (TC) concentrations of PCOS patients have been investigated in twelve studies and 2016. Five of them reported nonsignificant increases $[54,56,58,90,102]$. Additionally, five other studies reported significant increases in the TC levels of PCOS patients $[53,59,61,63,100]$. One single study reported a nonsignificant decrease [95] and another study reported a significant decrease in TC levels [94]. The analysis of these twelve studies as a whole group, demonstrated that TC levels increased from $173.7 \mathrm{mg} / \mathrm{dl}$ to $189.1 \mathrm{mg} / \mathrm{dl}$, an increase of $15.4 \mathrm{mg} / \mathrm{dl}(p=0.012)$. Overall, it can be concluded that the use of COC containing CPA by PCOS patients causes a significant increase in TC concentrations. So, its use in dyslipidemic PCOS patients should not be recommended.

The role of COCs with DRSP on the TC levels of PCOS patients were examined in nine studies. Two studies reported a nonsignificant increase of TC [70, 96], six studies demonstrated a significant increase [54, 69, $72,74,75,100]$, and one single study demonstrated a significant decrease [101]. In combination, all nine studies presented a nonsignificant increase in the TC levels, from $171.5 \mathrm{mg} / \mathrm{dl}$ to 185.2 , an increment of $13.7 \mathrm{mg} / \mathrm{dl}$ $(p=0.085)$. As a whole group, the studies demonstrated that COCs with DRSP also increase TC levels in PCOS patients, of course with small and low intensity than COCs with CPA in their formulation.

In one single study EE combined with CMA showed a significant increase in the TC levels, increasing it from $161.1 \mathrm{mg} / \mathrm{dl}$ to $193.2 \mathrm{mg} / \mathrm{dl}(p<0.05)$ [81]. The impact of COCs with $30 \mu \mathrm{g}$ EE and 75-150 $\mu \mathrm{g}$ DSG on the TC of PCOS patients were an increase from $158.9 \mathrm{mg} / \mathrm{dl}$ to $178.8 \mathrm{mg} / \mathrm{dl}$, increase of $20 \mathrm{mg} / \mathrm{dl}(p=0.108)$ [61, 74, 103]. A preparation with GSD increased the TC levels from $188.4 \mathrm{mg} / \mathrm{dl}$ to $198.8 \mathrm{mg} / \mathrm{dl}(p>0.05)$ [85]. Combined $30 \mu \mathrm{g}$ EE and 180-250 $\mu \mathrm{g}$ NGM increased TC levels from $168.9 \mathrm{mg} / \mathrm{dl}$ to $181.7 \mathrm{mg} / \mathrm{dl}(p=0.060)$ in two studies [99, 111]. COCs with LNG increased TC from $161.8 \mathrm{mg} / \mathrm{dl}$ to $170.4 \mathrm{mg} / \mathrm{dl}(p=0.265)[86,103]$. Collectively, the results indicate that most COC preparations increase the TC levels of PCOS patients and, currently, there does not exist a preferred formulation. This fact must be considered for proper COC prescription in dyslipemic conditions.

\section{Low-density lipoprotein cholesterol}

The possible changes in LDL-C levels in PCOS patients who used COCs containing CPA was examined in eleven clinical studies. Three studies presented nonsignificant decreases in LDL-C $[56,90,102]$ and five other studies have found nonsignificant increases in the LDL-C $[53,54,59,95,103]$. Two studies demonstrated a significant increase [61,63] and another one showed a significant decrease [100] in the LDL-C levels with the CPA pill. As a whole, these studies demonstrated that with the pill containing CPA, LDL-C increased from $98 \mathrm{mg} / \mathrm{dl}$ to $101.9 \mathrm{mg} / \mathrm{dl}(p=0.241)$. Therefore, the results regarding LDL-C levels in PCOS patients who used COCs containing CPA are inconsistent but leaning towards a small nonsignificant increase.

PCOS patients using COCs with DRSP may have a nonsignificant decrease in their LDL-C levels [91, 96]. In addition, a significant decrease was recently found [74, 101]. Besides, two studies have reported significant increases in LDL-C levels $[69,100]$ and two other studies also have found nonsignificant increases [54, 72]. Therefore, data 
Table 7 Influence of different combined oral contraceptive formulations in the lipid concentrations of polycystic ovary syndrome

\begin{tabular}{|c|c|c|c|c|c|}
\hline COC formulation & Number of studies & $\begin{array}{l}\text { Before } \\
\text { Md (1st - 3rd) }\end{array}$ & $\begin{array}{l}\text { After } \\
\text { Md (1st - 3rd) }\end{array}$ & $\Delta$ & $p^{*}$ \\
\hline \multicolumn{6}{|l|}{ Total Cholesterol (mg/dl) } \\
\hline EE $35 \mu \mathrm{g} /$ CPA 2 mg & 12 & $173.7(162.1-184.1)$ & $189.0(185.3-200.9)$ & +15.3 & 0.012 \\
\hline EE 30 mg / DRSP 3 mg & 09 & $171.5(166.8-185.9)$ & $185.2(167.3-203.1)$ & 13.7 & 0.085 \\
\hline EE $30 \mu \mathrm{g} / \mathrm{DSG} 75-150 \mu \mathrm{g}$ & 03 & $158.9(154.9-162.9)$ & $178.8(169.0-188.4)$ & +19.5 & 0.108 \\
\hline EE $30 \mu \mathrm{g} / 180-250 \mu \mathrm{g}$ NGM & 02 & $168.9(167.6-170.2)$ & $181.7(181.3-182.1)$ & +12.8 & 0.060 \\
\hline EE $30 \mu \mathrm{g} / 150 \mu \mathrm{g}$ LNG & 02 & $161.8(158.4-165.2)$ & $170.4(169.1-173.8)$ & +8.6 & 0.265 \\
\hline \multicolumn{6}{|l|}{ LDL-C (mg/dl) } \\
\hline EE $35 \mu \mathrm{g} /$ CPA 2 mg & 11 & $98.0(91.0-103.9)$ & $101.9(86.8-114.6)$ & +3.9 & 0.241 \\
\hline EE 30 mg / DRSP 3 mg & 08 & $95.2(87.6-107.0)$ & $101.3(92.6-113.1)$ & +6.1 & 0.345 \\
\hline EE $30 \mu \mathrm{g} /$ CMA $2 \mu \mathrm{g}$ & 03 & $101.5(99.6-103.4)$ & $100.9(98.3-103.5)$ & +0.6 & 0.486 \\
\hline EE $30 \mu \mathrm{g} / \mathrm{DSG} 75-150 \mu \mathrm{g}$ & 03 & $94.3(94.0-94.5)$ & $106.8(100.9-112.7)$ & +12.5 & 0.108 \\
\hline EE $30 \mu \mathrm{g} / \mathrm{NGM} 180-250 \mu \mathrm{g}$ & 02 & $100.2(99.9-100.5)$ & $107.6(106.7-108.3)$ & +7.4 & 0.031 \\
\hline EE $30 \mu \mathrm{g} / \mathrm{LNG} 150 \mu \mathrm{g}$ & 02 & $87.2(77.4-97.0)$ & $90.6(80.2-101.0)$ & +3.4 & 0.022 \\
\hline \multicolumn{6}{|l|}{$\mathrm{HDL}-\mathrm{C}(\mathrm{mg} / \mathrm{dl})$} \\
\hline EE 35 mg / CPA 2 mg & 10 & $54.3(50.2-59.5)$ & $61.5(60.7-67.2)$ & +7.3 & 0.020 \\
\hline EE 30 mg / DRSP 3 mg & 08 & $59.5(50.0-62.5)$ & $73.3(64.5-79.7)$ & +13.8 & 0.017 \\
\hline EE $30 \mu \mathrm{g} /$ CMA 2 mg & 03 & $51.1(49.9-52.3)$ & $61.4(61.1-61.7)$ & +10.3 & 0.108 \\
\hline EE $30 \mu \mathrm{g} / \mathrm{DSG} 75 / 150 \mu \mathrm{g}$ & 03 & $49.6(34.7-59.7)$ & $45.3(26.0-75.0)$ & -3.3 & 0.592 \\
\hline \multicolumn{6}{|l|}{ TG (mg/dl) } \\
\hline EE 35 rg / CPA 2 mg & 11 & $81.4(69.0-99.1)$ & $104.0(85.8-123.4)$ & +22.6 & 0.021 \\
\hline EE $30 \mu \mathrm{g} / \mathrm{DRSP} 3 \mathrm{mg}$ & 07 & $95.0(72.8-105.6)$ & $116.8(115.0-138.9)$ & +21.8 & 0.017 \\
\hline EE $30 \mu \mathrm{g} /$ CMA 2 mg & 03 & $83.9(83.6-84.2)$ & $125.5(116.1-134.9)$ & +41.6 & 0.108 \\
\hline EE $30 \mu \mathrm{g} / \mathrm{DSG} 75-150 \mu \mathrm{g}$ & 03 & $87.7(83.7-91.7)$ & $108.3(102.4-114.2)$ & +20.6 & 0.137 \\
\hline EE $30 \mu \mathrm{g} / \mathrm{NGM} 180-250 \mu \mathrm{g}$ & 03 & $104.7(86.1-123.3)$ & $134.3(117.4-151.3)$ & +29.6 & 0.025 \\
\hline
\end{tabular}

COC combined oral contraceptive, Md (1st - 3rd) median, first and third quartiles, LDL-C low-density lipoprotein cholesterol, HDL-C high-density lipoprotein cholesterol, TG triglyceride, CPA cyproterone acetate, DRSP drospirenone, CMA chlormadinona acetate, DSG desogestrel, NGM norgestimate, LNG levonorgestrel p* Wilcoxon signed- ranks test

regarding LDL-C levels in PCOS patients who used a pill with DRSP are inconsistent. Collectively, COCs with this combination increased LDL-C levels from $95.2 \mathrm{mg} / \mathrm{dl}$ to $101.3 \mathrm{mg} / \mathrm{dl}(p=0.345)$ and these results allowed to concluded that regarding LDL-C levels, COCs with DRSP have no additional risk in PCOS patients.

The influence of COCs with CMA in the LDL-C levels of PCOS patients are insignificant $[75,80,81]$ and LDL-C levels changed from $101.5 \mathrm{mg} / \mathrm{dl}$ to $100.9 \mathrm{mg} / \mathrm{dl}(p=$ $0.486)$ with this preparation. COCs containing DSG induced a nonsignificant increase from $94.3 \mathrm{mg} / \mathrm{dl}$ to $106.8 \mathrm{mg} / \mathrm{dl}(p=0.108)[61,74,103]$ in the LDL-C levels of PCOS patients. One single study reported a nonsignificant increase from $112.7 \mathrm{mg} / \mathrm{dl}$ to $117.7 \mathrm{mg} / \mathrm{dl}(p=0.053)$ in the LDL-C levels of PCOS patients who used COCs containing GSD [85]. COCs with EE $30 \mu \mathrm{g}$ and NGM $180-250 \mu \mathrm{g}$ increased LDL-C from $100.2 \mathrm{mg} / \mathrm{dl}$ to $107.6 \mathrm{mg} / \mathrm{dl}(p=0.031)$ [99, 111]. The combination of $30 \mu \mathrm{g} \mathrm{EE}$ and $150 \mu \mathrm{g}$ LNG increased LDL-C from $87.2 \mathrm{mg} / \mathrm{dl}$ to $90.6 \mathrm{mg} / \mathrm{dl}(p=0.022)[86,103]$. Collectively, the studies reporting the impact of COCs on the LDL-C levels are inconsistent but combinations with GSD, LNG, and NGM progestins might be preferred in opposite to those with CPA and DRSP progestins.

\section{Triglycerides}

The impact of COC preparations containing CPA on the TG levels were reported in eleven clinical studies. It was demonstrated a significant increase of TG levels in seven studies [56, 59-61, 63, 90, 102]. Nonsignificant decrease in two other studies were also described [53, 94]. In one single study, the TG levels did not change at all [98], and in another trial, a significant decrease was found with this preparation [100]. The analysis of all eleven studies using the Wilcoxon test showed that TG levels were increased from $81.4 \mathrm{mg} / \mathrm{dl}$ to $104 \mathrm{mg} / \mathrm{dl}(p=$ 0.021). Therefore, COCs containing the CPA progestin significantly increase TG levels of PCOS patients.

EE combined with DRSP that was used by PCOS patients produced a significant increase in TG concentrations 
in six studies $[69,72,74,91,96,100]$ and this increase was not significant in just one study [75]. Testing the seven studies as a whole group, TG levels increased from $95 \mathrm{mg} /$ dl to $116.8 \mathrm{mg} / \mathrm{dl}$, a difference of $21.8 \mathrm{mg} / \mathrm{dl}(p=0.017)$. So, COCs containing DRSP significantly increase TG levels in blood. COCs with CMA also increased the TG levels of PCOS patients from $83.9 \mathrm{mg} / \mathrm{dl}$ to $125.5 \mathrm{mg} / \mathrm{dl}$, a nonsignificant increase of $41.6 \mathrm{mg} / \mathrm{dl}(p=0.137)$ [75, 80, 81]. DSG combined with $30 \mu \mathrm{g}$ EE produced a nonsignificant TG level increase from $87.7 \mathrm{mg} / \mathrm{dl}$ to $108.3 \mathrm{mg} / \mathrm{dl}(p=$ 0.108) $[74,103,117]$.

The pill with GSD also increased LDL-C from $112.7 \mathrm{mg} /$ $\mathrm{dl}$ to $117.7 \mathrm{mg} / \mathrm{dl}(p>0.05)$ [85]. The combination of $30 \mu \mathrm{g}$ EE with NGM significantly increased TG levels from $104.7 \mathrm{mg} / \mathrm{dl}$ to $134.3 \mathrm{mg} / \mathrm{dl}(p=0.025)$ [99, 109, 111]. COCs combining EE and LNG increased TG levels from $136.1 \mathrm{mg} / \mathrm{dl}$ to $102.5 \mathrm{mg} / \mathrm{dl}(p=0.377)[86,103]$. Collectively, it can be considered that COCs, independent of progestin preparation, can increase the TG levels of PCOS patients. Therefore, the presence of hypertriglyceridemia should be considered before any COC prescription. Combinations containing CMA, and DSG seem to present a lower impact on TG levels of PCOS women.

\section{Conclusions}

Collectively, the available studies, either randomized controlled trials or prospective observational, suggest that the use of different COCs preparations do not get worse or bring additional harm for PCOS users, at least when used for 3-6 months. Because of remarkable decrease in androgen and increase in SHBG concentrations, hyperandrogenemic PCOS phenotype patients may have greater benefits and antiandrogenic progestins are preferred in patients with this phenotype. PCOS patients with hypertension, or central obesity, can use any $\mathrm{COC}$ preparation, however evidence is lacking. Scarce data suggests that preparations containing antiandrogenic/antimineralocorticoid progestin could be chosen. Regarding carbohydrate metabolism changes in PCOS patients, the published data indicate that COCs do not make it worse or significantly increase baseline blood concentrations of them. Apart from that, COCs with DRSP and DSG may decrease HOMA-IR improving tissue insulin sensitivity. TC, TG, and HDL-C are consistently increased by COCs but the clinical implications of these changes still need more long-term investigation. Despite the fact that there is no clear advantage of one preparation over other, it is recommended that lipid baseline levels should be measured to help chosing a particular COC preparation for dyslipidemic patients.

\section{Acknowledgements}

The author is grateful to American Journal of Experts for English revision.

\section{Funding}

The author has not received any financial support for this study.
Availability of data and materials

The author transfer copyright to BioMed Central.

\section{Authors' contributions}

The author was responsible for design, literature search, literature reading and analysis, writing and revision of the manuscript.

Ethics approval and consent to participate

There is no need for Ethics approval by this design of study (only a review of published data was performed).

\section{Consent for publication}

The author declares that he/she has no competing interests.

\section{Competing interests}

The author declares that he has no competing interests.

\section{Publisher's Note}

Springer Nature remains neutral with regard to jurisdictional claims in published maps and institutional affiliations.

Received: 2 August 2017 Accepted: 30 November 2017

Published online: 08 December 2017

\section{References}

1. de Medeiros SF, Barbosa JS, Yamamoto MMW. Comparison of steroidogenic pathways among normoandrogenic and hyperandrogenic polycystic ovary syndrome patients and normal cycling women. J Obstet Gynaecol Res. 2015;41:254-63.

2. McCartney CR, Marshall JC. Polycystic ovary syndrome. New Engl J Med. 2016;375:54-64

3. Fauser BC, Tarlatzis BC, Rebar RW, Legro RS, Balen AH, Lobo R, Carmina E, Chang J, Yildiz BO, Laven JS, Boivin J, et al. Consensus on women's health aspects of polycystic ovary syndrome (PCOS): the Amsterdam ESHRE/ASRMSponsored 3rd PCOS Consensus Workshop Group. Fertil Steril. 2012; 97:2838.e25.

4. Targher G, Zoppini G, Bonora E, Moghetti P. Hemostatic and fibrinolytic abnormalities in polycystic ovary syndrome. Semin Thromb Hemost. 2014; 40:600-18.

5. Legro RS, Arslanian SA, Ehrmann DA, Hoeger KM, Murad MH, Pasquali R, Welt CK. Diagnosis and treatment of polycystic ovary syndrome: an Endocrine Society clinical practice guideline. J Clin Endocrinol Metab. 2013; 98:4565-92.

6. Mendoza N, Simoncini T, Genazzani AD. Hormonal contraceptive choice for women with PCOS: a systematic review of randomized trials and observational studies. Gynecol Endocrinol. 2014;30:850-60.

7. Korytkowski MT, Mokan M, Horwitz MJ, Berga SL. Metabolic effects of oral contraceptives in women with polycystic ovary syndrome. J Clin Endocrinol Metab. 1995;80:3327-34.

8. Yildiz BO. Oral contraceptives in polycystic ovary syndrome: risk-benefit assessment. Semin Reprod Med. 2008;26:111-20.

9. Yildiz BO. Approach to the patient: contraception in women with polycystic ovary syndrome. J Clin Endocrinol Metab. 2015;100:794-802.

10. Dokras A. Noncontraceptive use of oral combined hormonal contraceptives in polycystic ovary syndrome-risks versus benefits. Fertil Steril. 2016;106: 1572-9.

11. De Melo AS, Reis RM, Ferriani RA, Vieira CS. Hormonal contraception in women with polycystic ovary syndrome: choices, challenges, and noncontraceptive benefits. J Contracept. 2017;8:13-23.

12. de Groot PC, Dekkers OM, Romijn JA, Dieben SW, Helmerhorst FMPCOS. Coronary heart disease, stroke and the influence of obesity: a systematic review and meta-analysis. Hum Reprod Update. 2011;17:495-500.

13. Okoroh EM, Hooper WC, Atrash HK, Yusuf HR, Boulet SL. Is polycystic ovary syndrome another risk factor for venous thromboembolism? United States, 2003-2008. Am J Obstet Gynecol. 2012; 207:377.e-1-377.e-8.

14. de Bastos M, Stegeman BH, Rosendaal FR, Van Hylckama VA, Helmerhorst FM, Stijnen T, Dekkers OM. Combined oral contraceptives: venous thrombosis. Cochrane Database Syst Rev. 2014;3(3):CD010813.

15. Silverstein MD, Heit JA, Mohr DN, Petterson TM, O'Fallon WM, Melton $L$ 3rd. Trends in the incidence of deep vein thrombosis and pulmonary embolism: a 25-year population-based study. Arch Intern Med 1998; 158:585-593. 
16. Atiomo WU, Pearson S, Shaw S, Prentice A, Dubbins P. Ultrasound criteria in the diagnosis of polycystic ovary syndrome (PCOS). Ultrassound Med Biol. 2000;26:977-80.

17. Mak W, Dokras A. Polycystic ovarian syndrome and the risk of cardiovascular disease and thrombosis. Semin Thromb Hemost. 2009;35:613-20.

18. Bird ST, Hartzema AG, Brophy JM, Etminam M, Delaney JA. Risk of venous thromboembolism in women with polycystic ovary syndrome: a population-based matched cohort analysis. CMAJ. 2013;185:E115-20.

19. Anderson SA, Varry JA, Hardiman PJ. Risk of coronary heart disease and risk of stroke in women with polycystic ovary syndrome: a systematic review and meta-analysis. Inter. J Cardiol. 2014;176:486-7.

20. Matthesen T, Rasmussen AMO, Nielsen LH, Lidegaard O. Polycystic ovary syndrome hormonal contraception and thrombotic stroke: a historical cohort study. J Neurol Disord Stroke. 2015;3:1-7.

21. Cibula D, Cifkova R, Fanta M, Poledne R, Zivny J, Skibova J. Increased risk of non-insulin dependent diabetes mellitus, arterial hypertension and coronary artery disease in permenopausal women with a history of the polycystic ovarysyndrome. Hum Reprod. 2000;15:785-9.

22. Wild S, Pierpoint T, McKeique $\mathrm{P}$, Jacobs H. Cardiovascular disease in women with polycystic ovary syndrome at long-term follow-up: a retrospective cohort study. Clin Endocrinol. 2000;52:595-600.

23. Solomon CG, Hu FB, Dunaif A, Rich-Edwards JE, Stampfer MJ, Willett WC, Speizer FE, Manson JE. Menstrual cycle irregularity and risk for future cardiovascular disease. J Clin Endocrinol Metab. 2002;87:2013-7.

24. Zhao L, Zhu Z, Lou H, Zhu G, Huang W, Zhang S, Liu F. Polycystic ovary syndrome (PCOS) and the risk of coronary heart disease (CHD): a metaanalysis. Oncotarget. 2016;7:33715-21.

25. Wild RA, Grubb B, Hartz A, Van Nort JJ, Bachmann W, Bartholomew M. Clinical signs of androgen excess as risk factors for coronary artery disease. Fertil Steril. 1990;54:255-9.

26. Wiltgen D, Spritzer PM. Variation in metabolic and cardiovascular risk in women with different polycystic ovary syndrome phenotypes. Fertil Steril. 2010;94:2493-6.

27. Cibula D, Sindelka G, Hill M, Fanta M, Skrha J, Zivny J. Insulin sensitivity in non-obese women with polycystic ovary syndrome during treatment with oral contraceptives containing low-androgenic progestin. Hum Reprod. 2002;17:76-82.

28. Practice Committee of American Society for Reproductive Medicine. Combined hormonal contraception and the risk of venous thromboembolism: a guideline. Fertil Steril. 2017;107:43-51.

29. Stampfer MJ, Willett WC, Colditz GA, Speizer FE, Hennekens CHA. Prospective study of past use of oral contraceptive agents and risk of cardiovascular diseases. N Engl J Med. 1988;319:1313-7.

30. Fallah S, Nourozzi V, Seifi M, Samadikuchaksaraei A, Aghdashi EM. Influence of oral contraceptive pills on homocysteine and nitric oxide levels: as risk factors for cardiovascular disease. J Clin Lab Anal. 2012;26:120-3.

31. Dunn N, Thorogood M, Faragher B, Caestecker L, MacDonald T, McCollum C, Thomas S, Mann K. Oral contraceptives and myocardial infarction: results of the MICA case-control study. BMJ. 1999;318:1579-84.

32. Sidney S, Cheetham TC, Connell FA, Ouellet-Hellstrom R, Graham DJ, Davis D, Sorel M, Quesenberry CP Jr, Cooper WO. Recent combined hormonal contraceptives (CHCs) and the risk of thromboembolism and other cardiovascular events in new users. Contraception. 2013;87:93-100.

33. Tanis BC, van den Bosch MAAJ, Kemmeren JM. Oral contraceptives and the risk of myocardial infarction. New Engl J Med. 2001;345:1787-93.

34. Vinogradova Y, Coupland C, Hippisley-Cox J. Use of combined oral contraceptives and risk of venous thromboembolism: nested case-control studies using the QResearch and CPRD databases. BMJ. 2015; 26:350:h2135.

35. WHO Collaborative Study. Of cardiovascular disease and steroid hormone contraception. Acute myocardial infarction and combined oral contraceptives: results of an international multicentre case-control study. Lancet. 1997;349:1202-9.

36. Seaman HE, de Vries CS, Farmer RD. The risk of venous thromboembolism in women prescribed cyproterone acetate in combination with ethinyl estradiol: a nested cohort analysis and case-control study. Hum Reprod. 2003;18:522-6.

37. Vrbíková J, Cibula D. Combined oral contraceptives in the treatment of polycystic ovary syndrome. Hum Reprod Update. 2005;11:277-91.

38. Sitruk-Ware R, Nath A, Mishell DR Jr. Contraception technology: past, present and future. Contraception. 2013;87:319-30.

39. Mes-Krowinkel MG, Louwers YV, Mulders AGMGJ, de Jong FH, Fauser BC, Laven JS. Influence of oral contraceptives on anthropomorphometric, endocrine, and metabolic profiles of anovulatory polycystic ovary syndrome patients. Fertil Steril. 2014;101:1757-65.

40. Yildiz BO, Bozdag G, Yapici Z, Esinler I, Yarali H. Prevalence, phenotype and cardiometabolic risk of polycystic ovary syndrome under different diagnostic criteria. Hum Reprod. 2012;27:3067-73.

41. Dunaif A, Fauser BC. Renaming PCOS-a two state solution. J Clin Endocrinol Metab. 2013;98:4325-8.

42. Halperin IJ, Stroup DF, Laredo SE. The association between the combined oral contraceptive pill and insulin resistance, dysglycemia and dyslipidemia in women with polycystic ovary syndrome: a systematic review and metaanalysis of observational studies. Hum Reprod. 2011;26:191-201.

43. Haffner SM, Katz MS, Stern MP, Stern MP, Dunn JF. Association of decreased sex hormone binding globulin and cardiovascular risk factors. Arteriosclerosis. 1989;9:136-43.

44. Ding EL, Song Y, Manson J, Hunter DJ, Lee CC, Rifai N, Buring JE, Gaziano JM, Liu S. Sex hormone-binding globulin and risk of type 2 diabetes in women and men. N Engl J Med. 2009;361:1152-63.

45. Lapidus L, Lindstedt G, Lundberg PA, Bengtsson C, Gredmark T. Concentrations of sex-hormone binding globulin and corticosteroid binding globulin in serum in relation to cardiovascular risk factors and to 12-year incidence of cardiovascular disease and overall mortality in postmenopausal women. Clin Chem. 1986;32:146-52.

46. Sutton-Tyrrel K, Wildman RP, Matthews KA, Chae C, Lasley BL, Brockwell S, Pasternak RC, Lloyd-Jones D, Sowers MF, Torréns Jl. Sex-hormone binding globulin and the free androgen index are related to cardiovascular risk factors in multiethnic premenopausal and perimenopausal women enrolled in the study of women across the nation (SWAN). Circulation. 2005;111: 1242-9.

47. Shin JY, Kim SK, Lee MY, Kim HS, Ye BL, Shin YG, Baik SK, Chung CH. Sex hormone-binding globulin levels are independently associated with nonalcoholic fatty liver disease in people with type 2 diabetes. Diabetes Res Clin Pract. 2011:94:156-62.

48. Simó R, Sáez-López C. Barbosa-Deongles, Hernandez C, Selva D. Novel insights in SHBG regulation and clinical implications. Trend. Endocrinol Metab. 2015;26:376-83.

49. Cullberg G, Hamberger L, Mattsson LA, Mobacken H, Samsioe G. Effects of a low-dose desogestrel-ethinylestradiol combination on hirsutism, androgens and sex hormone binding globulin in women with a polycystic ovary syndrome. Acta Obstet Gynecol Scand. 1985;64:195-202.

50. Wiegratz I, Kutschera E, Lee JH, Moore C, Mellinger U, Winkler U, Kuhl H. Effect of four different oral contraceptives on various sex hormones and serum-binding globulins. Contraception. 2003;67:25-32.

51. Zimmerman Y, Eijkemans MJC, Coelingh Bennink HJT, Blankenstein MA, Fauser BC. The effect of combined oral contraception on testosterone levels in healthy women: a systematic review and meta-analysis. Hum Reprod Update. 2014;20:76-105.

52. Bhattacharya SM, Jha A. Comparative study of the therapeutic effects of oral contraceptive pills containing desogestrel, cyproterone acetate, and drospirenone in patients with polycystic ovary syndrome. Fertil Steril. 2012;98:1053-9.

53. Elter K, Imir G, Durmusoglu F. Clinical, endocrine and metabolic effects of metformin added to ethinylestradiol-cyproterone acetate in non-obese women with polycystic ovarian syndrome: a randomized controlled study. Hum Reprod. 2002:17:1729-37.

54. Kahraman K, Sükür YE, Atabekoğlu CS, Ates C, Taskim S, Cetinkaya SE, Tolunay HE, Ozmen B, Sonmezer M, Berker B. Comparison of two oral contraceptive forms containing cyproterone acetate and drospirenone in the treatment of patients with polycystic ovary syndrome: a randomized clinical trial. Arch Gynecol Obstet. 2014;290:321-8.

55. Cagnacci A, Tirelli A, Renzi A, Volpe A. Effects of two different oral contraceptives on homocysteine metabolism in women with polycystic ovary syndrome. Contraception. 2006;73:348-51.

56. Falsetti L, Galbignani E. Long-term treatment with the combination ethinylestradiol and cyproterone acetate in polycystic ovary syndrome. Contraception. 1990;42:611-9.

57. Golland IM, Elstein ME. Results of a one year open study with Diane-35 in women with polycystic ovary syndrome. Ann N Y Acad Sci. 1993;687:263-71.

58. Armstrong VL, Wiggam MI, Ennis CN, Sheridan B, Atkinson AB, Bell PM. Insulin action and insulin secretion in polycystic ovary syndrome treated with ethinyloestradiol/cyproterone acetate. Q J Med. 2001;94:31-7.

59. Naka KK, Kalantaridou SN, Bechlioulis A. Effect of ethinylestradiol/ cyproterone acetate on endothelial function in young non-obese women 
with polycystic ovary syndrome: a pilot study. Gynecol Endocrinol. 2011;27: 615-21.

60. Morin-Papunen L, Rautio K, Ruokonen A, Hedberg P, Puukka M, Tapanainen JS. Metformin reduces serum C-reactive protein levels in women with polycystic ovary syndrome. J Clin Endocrinol Metab. 2003;88:4649-54.

61. Mastorakos G, Koliopoulos C, Deligeoroglou E, Diamanti-Kandarakis E, Creatsas $G$. Effects of two forms of combined oral contraceptives on carbohydrate metabolism in adolescents with polycystic ovary syndrome. Fertil Steril. 2006;85:420-7.

62. Christakou C, Kollias A, Piperi C, Katsikis I, Panidis D, Diamanti-Kandarsakis E. The benefit-to-risk of common treatments in PCOS: effect of oral contraceptives versus metformin on antherogenic markers. Hormones. 2013;4:488-97.

63. Chen MJ, Yang WS, Chen HF, Kuo JJ, Ho HN, Yang YS, Chen SU. Increased follistatin levels after oral contraceptive treatment in obese and non-obese women with polycystic ovary syndrome. Hum Reprod. 2010;25:779-85.

64. Prelevic GM, Würzburger MI, Balint-Peric L, Puzigaca Z. Effects of a low-dose estrogen-antiandrogen combination (Diane-35) on clinical signs of androgenisation, hormone profile and ovarian size in patients with polycystic ovary syndrome. Gynecol Endocrinol. 1989;3:269-80.

65. Guido M, Romualdi D, Giuliani M, Suriano R, Selvaggi L, Apa R, Lanzone A. Drospirenone for the treatment of hirsute women with polycystic ovary syndrome: a clinical, endocrinological, metabolic pilot study. J Clin Endocrinol Metab. 2004;89:2817-23.

66. Pehlivanov B, Mitkov M. Efficacy of an oral contraceptive containing drospirenone in the treatment of women with polycystic ovary syndrome. Eur J Contracept Reprod Health Care. 2007;12:30-5.

67. Lello S, Primavera G, Colonna L, Vittori G, Guardianelli F, Sorge R, Raskovic D. Effects of two estroprogestins containing ethynilestradiol 30 microg and drospirenone $3 \mathrm{mg}$ and ethynilestradiol 30 microg and chlormadinone 2 mg on skin and hormonal hyperandrogenic manifestations. Gynecol Endocrinol. 2008;24:718-23.

68. Oner $\mathrm{G}$, Muderris II. A Prospective randomized trial comparing low-dose ethinylestradiol and drosperionone 24/4 combined oral contraceptive vs ethinyl estradiol and drospirenone $21 / 7$ combined oral contraceptive in the treatment of hirsutism. Contraception. 2011;84:508-11.

69. Aydin K, Cinar N, Aksoy DY, Bozdag G, Yildiz BO. Body composition in lean womrn with polycystic ovary syndrome: effect of ethinyl estradiol and drosperinone combination. Contraception. 2013;87:358-62.

70. Harmanci A, Cinar N, Bayraktar M, Yildiz B. Oral contraceptive plus antiandrogen therapy and cardiometabolic risk in polycystic ovary syndrome. Clin Endocrinol. 2013;78:120-5.

71. Batukan C, Muderris II. Efficacy of a new oral contraceptive containing drospirenone and ethinyl estradiol in the long-term treatment of hirsutism. Fertil Steril. 2006;85:436-40.

72. Battaglia C, Mancini F, Fabbri R, Persico N, Busacchi P, Facchinetti F, Venturoli S. Polycystic ovary syndrome and cardiovascular risk in young patients treated with drospirenone-ethinylestradiol or contraceptive vaginal ring. A prospective, randomized, pilot study. Fertil Steril. 2010;94:1417-25.

73. De Leo V, Di Sabatino A, Musacchio MC, Morgante G, Scolaro V, Cianci A, Petraglia F. Effect of oral contraceptives on markers of hyperandrogenism and SHBG in women with polycystic ovary syndrome. Contraception. 2010; 82:276-80

74. Kriplani A, Priyasamy AJ, Agarwal N, Kulshrestha V, Kumar A, Ammini AC. Effect of oral contraceptive containing ethinyl estradiol combined with drosperinone VS desogestrel on clinical and biochemical parameters in patients with polycystic ovary syndrome. Contraception. 2010;82:139-46.

75. Yildizhan R, Gokce Al, Yildizhan B, Cim N. Comparison of the effects of chlormadinone acetate versus drospirenone containing oral contraceptives on metabolic and hormonal parameters in women with PCOS for a period of two-year follow-up. Gynecol Endocrinol. 2015;31:396-400.

76. Romualdi D, De Cicco S, Busacca M, Gagliano D, Lanzone A, Guido M. Clinical efficacy and metabolic impact of two different dosages of ethynil-estradiol in association with drospirenone in normal-weight women with polycystic ovary syndrome: a randomized study. J Endocrinol Investig. 2013;36:636-41.

77. Bhattacharya SM, Jha A, DasMukhopadhyay L. Comparison of two contraceptive pills containing drospirene and $20 \mu \mathrm{g}$ or $30 \mu \mathrm{g}$ ethinylestradiol for polycystic ovary syndrome. Int J Gynecol Obstet. 2016;132:210-3.

78. Klipping C, Marr J. Effects of two combined oral contraceptives containing ethinyl estradiol 20 microg combined with either drospirenone or desogestrel on lipids, hemostatic parameters and carbohydrate metabolism. Contraception. 2005;71:409-16.
79. Uras R, Orrú M, Pani F, Marotto MF, Pilloni M, Guerriero S, Etzi R, Zedda P, Sorge R, Lello $S$, Melis GB, et al. Endocrinological, metabolic and clinical features of treatment with oral contraceptive formulation containing ethinylestradiol plus chlormadione acetate in nonobese women with polycystic ovary syndrome. Contraception. 2010;82:131-8.

80. Gomes VA, Vieira CS, Jacob-Ferreira NA, Belo VA, Soares GM, França JB, Ferriani RA, Tanus-Santos JE. Oral contraceptive containing chlormadinone acetate and ethinylestradiol reduces plasma concentrations of matrix metalloproteinase-2 in women with polycystic ovary syndrome. Basic Clin Pharmacol Toxicol. 2012;111:211-6.

81. Vieira CS, Martins WP, Fernandes JB, Soares GM, dos Reis RM, de Sá MF, Ferriani RA. The effects of $2 \mathrm{mg}$ chormadinone acetate $/ 30 \mathrm{mcg}$ ethinylestradiol, alone or combined with spironolactone, on cardiovascular risk markers in women with polycystic ovary syndrome. Contraception. 2012:86:268-75.

82. Bouchard P. Chlormadinone acetate (CMA) in oral contraception-a new opportunity. Eur J Contracept Reprod Health Care. 2005;10(Suppl 1):7-11.

83. Matorakos G, Koliopoulos C, Creatsas C. Androgen and lipid profiles in adolescents with polycystic ovary syndrome who were treated with two forms of combined oral contraceptives. Fertil Steril. 2002;77:919-27.

84. Rojanasajul A, Sirimongkolkasem R, Piromsawasdi S, Sumavong V. Chailurkit la-or, Chaturachinda K. Effects of combined ethinylestradiol and desogestrel on hormone profiles and sex hormone binding globulin in women polycystic ovarian disease. Contraception. 1987;36:633-40.

85. Minozzi M, Constantino D, Guaraldi C, Unfer V. The effect of a combination therapy with myo-inositol and a combined oral contraceptive pill alone on metabolic, endocrine, and clinical parameters in polycystic ovary syndrome. Gynecol Endocrinol. 2011;27:920-4.

86. Sitruk-Ware RL, Menard J, Rad M, Burggraaf J, De Kam ML, Tokay BA, Sivin I, Kluft C. Comparison of the impact of vaginal and oral administration of combined hormonal contraceptives on hepatic proteins sensitive to estrogen. Contraception. 2007;75:430-7.

87. White T, Ozel B, Jain JK, Stanczyk FZ. Effects of transdermal and oral contraceptives on estrogen-sensitive hepatic proteins. Contraception. 2006;4:293-6.

88. Sodergard R, Bäckström T, Shanbhag V, Carstensen H. Calculation of free and bound fractions of testosterone and estradiol-17 beta to human plasma proteins at body temperature. J Steroid Biochem. 1982;16:801-10.

89. Raudrant D, Rabe T. Progestogens with antiandrogenic properties. Drugs. 2003;63:463-92.

90. Falsetti L, Pasinetti E. Effects of long-term administration of an oral contraceptive containing ethinylestradiol and cyproterone acetate on lipid metabolism in women with polycystic ovary syndrome. Acta Obstet Gynecol Scand. 1995;74:56-60.

91. Ibañez L, de Zegher F. Flutamide-metformin plus an oral contraceptive (OC) for young women with polycystic ovary syndrome: switch from third- to fourth-generation OC reduces body adiposity. Hum Reprod. 2004;19:1725-7.

92. Nader S, Riad-Gabriel MG, Saad MF. The effect of a desogestrel-containing oral contraceptive on glucose tolerance and leptin concentrations in hyperandrogenic women. J Clin Endocrinol Metab. 1997;82:3074-7.

93. Glintborg D, Altinok ML, Mumm H, Hermann AP, Ravn P, Andersen M. Body composition is improved during 12 months' treatment with metformin alone or combined with oral contraceptives compared with treatment with oral contraceptives in polycystic ovary syndrome. J Clin Endocrinol Metab. 2014; 7:2584-91.

94. Bilgir O, Kebapcilar L, Taner C, Bilgir F, Kebapcilar A, Bozkaya G, Yildiz Y, Yuksel A, Sari I. The effect of ethinylestradiol (EE)/cyproterone acetate (CA) and EE/CA plus metformin treatment on adhesion molecules in cases with polycystic ovary syndrome (PCOS). Intern Med. 2009;48:1193-9.

95. Kebapcilar L, Taner CE, Kebapcilar AG, Alacacioglu A, Sari I. Comparison of four different treatment regimens on coagulation parameters, hormonal and metabolic changes in women with polycystic ovary syndrome. Arch Gynecol Obstet. 2010;281:35-42.

96. Palep-Singh M, Mook K, Barth J, Balen A. An observational study of Yasmin in the management of women with polycystic ovary syndrome. J Fam Plann Reprod Health Care. 2004;30:163-5.

97. Sänger N, Stahlberg S, Manthey T, Mittmann K, Mellinger U, Lange E, Kuhl H, Wiegratz I. Effects of an oral contraceptive containing $30 \mathrm{mcg}$ ethinyl estradiol and $2 \mathrm{mg}$ dienogest on thyroid hormones and androgen parameters: conventional vs. extended-cycle use. Contraception. 2008;6:420-5.

98. Di Carlo C, Gargano V, Sparice S, Tommaselli GA, Bifulco G, Schettino D, Nappi C. Short-term effects of an oral contraceptive containing 
oestradiolvalerate and dienogest on bone metabolism and bone mineral density: an observational, preliminary study. Eur J Contracept Reprod Health Care. 2013;18:388-93.

99. Adeniji AA, Essah PA, Nestler JE, Cheang Kl. Metabolic effects of a commonly used combined hormonal oral contraceptive in women with and without polycystic ovary syndrome. J Women's Health. 2016;25:638-45.

100. Wang QY, Song Y, Huang W. Comparison of drospirenone- with cyproterone acetate-containing oral contraceptives, combined with metformin and lifestyle modifications in women with polycystic ovary syndrome and metabolic disorders: a prospective randomized control trial. Chinese Med J. 2016;129:883-90.

101. Orio F, Muscogiuri G, Giallauria F, Savastano S, Bottiglieri P, Tafuri D, Predotti P, Colarieti G, Colao A, Palomba S. Oral contraceptives versus physical exercise on cardiovascular and metabolic risk factors in women with polycystic ovary syndrome: a randomized controlled trial. Clin Endocrinol. 2016;85:764-71.

102. Wu H, Ruan X, Jin J, Mueck AO. Metabolic profile of Diane-35 versus Diane35 plus metformin in Chinese PCOS women under standardized life-style changes. Gynecol Endocrinol. 2015:31:548-51.

103. Shahnazi M, Farshbaf-Khalili A, Pourzeinali-Beilankouh S, Sadrimehr F. Effects of second and third generation oral contraceptives on lipid and carbohydrate metabolism in overweight and obeses women: a randomized triple-blind controlled trial. Iran Red Crescent Med J. 2016;18:e36982.

104. Lindh I, Ellström AA, Milsom I. The long-term influence of combined oral contraceptives on body weight. Hum Reprod. 2011;26:1917-24.

105. Van der Vange N, Blankenstein MA, Kloosterboer HJ, Haspels AA, Thijssen $J$ H. Effects of seven low-dose combined oral contraceptives on sex hormone binding globulin, corticosteroid binding globulin, total and free testosterone. Contraception. 1990;41:345-52.

106. Milsom I, Lete I, Bjertnaes A, Rokstad K, Lindh I, Gruber CJ, Birkhäuser MH, Aubeny $\mathrm{E}$, Knudsen T, Bastianelli C. Effects on cycle control and bodyweight of the combined contraceptive ring, NuvaRing, versus an oral contraceptive containing 30 microg ethinylestradiol and $3 \mathrm{mg}$ drospirenone. Hum Reprod. 2006:21:2304-11.

107. Pasquali R, Gambineri A, Anconetani B, Vicennati V, Colitta D, Caramelli E, Casimirri F, Morselli-Labate AM. The natural history of the metabolic syndrome in young women with the polycystic ovary syndrome and the effect of long-term oestrogen-progestagen treatment. Clin Endocrinol. 1999; 50:517-27.

108. Kilic S, Yilmaz N, Zulfikaroglu E, Erdogan G, Aydin BS. Inflammatory-metabolic parameters in obese and nonobese normoandrogenemic polycystic ovary syndrome durinf metformin and oral contraceptive treatment. Gynecol Endocrinol. 2011;(9):622-9.

109. Cibula D, Fanta M, Vrbikova J, Stanicka S, Dvorakova K, Hill M, Skrha J, Zivny J, Skrenkova J. Effect of combination therapy with metformin and combined oral contraceptives (COC) versus COC alone on insulin sensitivity, hyperandrogenaemia, SHBG and lipids in PCOS patients. Hum Reprod. 2005; 20:180-4.

110. Gaspard U, Scheen A, Endrikat J, Buicu C, Lefebvre P, Gerlinger C, Heithecker RA. Randomized study over 13 cycles to assess the influence of oral contraceptives containing ethinylestradiol combined with drospirenone or desogestrel on carbohydrate metabolism. Contraception. 2003;67:423-9.

111. Essah PA, Arrowood JA, Cheang Kl, Adawadkar SS, Stovall DW, Nestler JE. Effect of combined metformin and oral contraceptive therapy on metabolic factors and endothelial function in overweight and obese women with polycystic ovary syndrome. Fertil Steril. 2011;2:501-4.

112. Celik C, Abali R, Bastu E, Tasdemir N, Tasdemir UG, Gul A. Assesment of impaired glucose tolerance with hemoglobin $A_{1 c}$ and oral glucose tolerance test in 252 Turkish women with polycystic ovary syndrome: a prospective, controlled study. Hum Reprod. 2013;28:1062-8.

113. Kim JJ, Choi YM, Cho YM, Jung HS, Chae SJ, Hwang KR, Hwang SS, SY K, Kim SH, Kim JG, et al. Prevalence of elevated glycated hemoglobin in women with polycystic ovary syndrome. Hum Reprod. 2012;27:1439-44.

114. de Medeiros SF, Yamamoto MMW, Bueno HB, Belizario D, Barbosa J. Prevalence of elevated glycated hemoglobin concentrations in the polycystic ovary syndrome: anthropometrical and metabolic relationship in Amazonian women. J Clin Med Res. 2014;6:278-86.

115. Nathan DM, Turgeon H, Regan S. Relationship between glycated haemoglobin levels and mean glucose levels over time. Diabetologia. 2007;50:2239-44.
116. Sadaria RG, Ravi BV. A study on assessment of testosterone, insulin resistance and $\mathrm{HbA} 1 \mathrm{c}$ in women with polycystic ovarian syndrome. Inter J Health Scien Res. 2015;5:180-5.

117. Mosorin AE, Piltonen T, Tapananainen J, Papunen-Mortin L. Both oral and vaginal combined hormonal contraceptive induce unbeneficial metabolic effects in women with PCOS: a randomized study. Endocr Abstr. 2017:49

\section{Submit your next manuscript to BioMed Central and we will help you at every step:}

- We accept pre-submission inquiries

- Our selector tool helps you to find the most relevant journal

- We provide round the clock customer support

- Convenient online submission

- Thorough peer review

- Inclusion in PubMed and all major indexing services

- Maximum visibility for your research

Submit your manuscript at www.biomedcentral.com/submit 